\title{
Morphological signatures of mass wasting and delta processes in a fjord-lake system: insights from Lovatnet, western Norway
}

\author{
Louise Hansen', Nicolas Waldmann², Joep E.A. Storms s', Raymond S. Eilertsen', Daniel \\ Ariztegui ${ }^{4}$, Emmanuel Chapron ${ }^{5}$ \& Atle Nesje ${ }^{5,6}$
}

\author{
${ }^{1}$ Geological Survey of Norway, Leiv Erikssons vei 39, N-7491 Trondheim, Norway. \\ ${ }^{2}$ The Dr. Moses Strauss Department of Marine Geosciences, Charney School of Marine Sciences, University of Haifa, Mount Carmel, 31905 Haifa, Israel. \\ ${ }^{3}$ Geoscience \& Engineering, Delft University of Technology, P.O. Box 5048, 2600 GA Delft, the Netherlands. \\ ${ }^{4}$ Section of Earth \& Environmental Sciences, University of Geneva, Rue des Maraichers 13, 1205 Geneva, Switzerland. \\ ${ }^{5}$ GEODE UMR 5602 CNRS-Université Toulouse Jean Jaurès, Maison de la Recherche, 5 Allée A. Machado, 31058 Toulouse cedex, France. \\ ${ }^{6}$ Department of Earth Science, University of Bergen, Allégaten 41, Bergen N-5007, Norway. \\ ${ }^{7}$ Bjerknes Centre for Climate Research, Allégaten 70, 5007 Bergen, Norway. \\ E-mail corresponding author (Louise Hansen): louise.hansen@ngu.no
}

High-resolution bathymetrical data from the Lovatnet lake, western Norway, reveal a diverse morphology including traces from historic and prehistoric landslides. Onshore LiDAR and selected seismic profiles support the interpretation. Our data from the lake show significant debris lobes below Ramnefjellet that was the source of the well-known rock avalanche and tsunami disasters in 1905 and 1936 which caused a total of 134 casualties. The debris is divided into three main lobes reaching a total length of $1.8 \mathrm{~km}$ along the lake bottom from the impact site, and diffuse lobe features below the Bødalsdelta. Frontal deformations are minor. Lobes on the basin plain have a volume of more than $1.2 \times 10^{6} \mathrm{~m}^{3}$ including debris entrained from the surrounding slopes and lake floor. The entire lake volume was set in motion during the catastrophic events. Returning bottom flows transported debris into the lake where lobes and minor, distinct mounds were deposited up to $c .1 .5 \mathrm{~km}$ from the lake's outlet. The mounds could be anthropogenic, and possibly include a vessel that disappeared during the event. Erosion and smaller failures occurred elsewhere in the lake basin. Fan-delta morphologies are varied, with ridges and protuberances, reflecting deltaic sedimentation interrupted by major mass-wasting or other events in the deltas and/or their catchments. This is especially clear for the Raudi, Hellsete and Bødalen deltas, but minor protuberances are also found in other deltas. The data also reveal traces from large and previously undocumented landslide events. Gravitational deposits generally dominate the steep slopes and glacial landforms are scarce. The study demonstrates the importance of linking onshore and offshore morphological datasets in order to obtain an overview over process variability in fjord-type lakes of importance for further investigation and hazard assessment.

Keywords: lake, bathymetry, landslide, delta, tsunami, Norway

Received 23. December 2015 / Accepted 13. May 2016 / Published online 16. June 2016

\section{Introduction}

High-resolution bathymetrical data provide detailed information on the variability of processes operating in fjords, fjord-type lakes and similar elongated basins. This includes the information on depositional products as well as the behaviour and causal relationships between sedimentary processes. Such information is especially crucial for the understanding of hazardous events in the basins (e.g., Bøe et al., 2003; Longva et al., 2003; Blikra et al., 2006; L'Heureux et al., 2009, 2012; Ledoux et al., 2010; Hilbe et al., 2011, 2014; Van Daele et al., 2013; Haeussler et al., 2014; Kremer et al., 2015; Wiemer et al., 2015). In

Hansen, L., Waldmann, N., Storms, J.E.A., Eilertsen, R.S., Ariztegui, D., Chapron, E. \& Nesje, A. 2016: Morphological signatures of mass wasting and delta processes in a fjord-lake system: insights from Lovatnet, western Norway. Norwegian Journal of Geology 96, 1-21. http://dx.doi.org/10.17850/ njg96-3-02. 


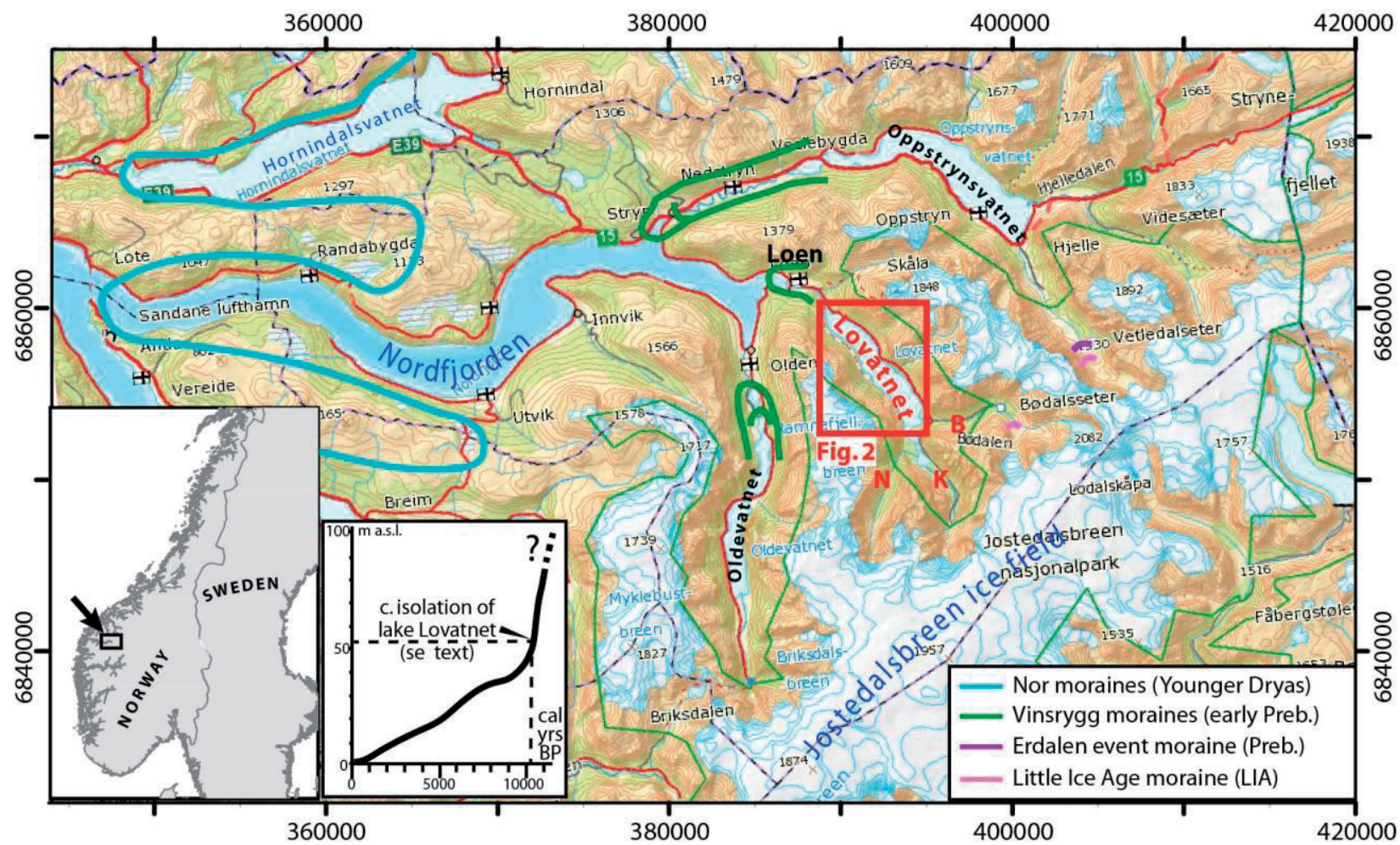

Figure 1. Location of Lovatnet in western Norway. Glacier marginal positions from Younger Dryas and the Holocene are indicated. The inset shows a tentative relative sea-level curve for the Lovatnet area with an indication of the possible timing of lake isolation. See text for more explanations. Abbreviations: $K$ - Kjenndalen, $N$ - Nesdal, B - Bødalen.

this context, the linkage of offshore-onshore datasets is crucial as it provides clues to the many processes that occur in both environments (e.g., Bozzano et al., 2009; Couchon-Voyer et al., 2011). In addition, the detailed bathymetrical data provide a basis for selecting the best locations for seismic profiling and subsequent coring. The combined offshore-onshore dataset also provides an ideal framework for the interpretation of the paleoenvironmental archive in the basins.

The present study focuses on the Lovatnet fjordtype lake system in Sogn and Fjordane county, western Norway. Lovatnet lake is located in one of several fjordvalley transects connecting the $100 \mathrm{~km}$-long Nordfjord with upstream valleys hosting outlet glaciers from the Jostedalsbreen ice cap (Fig. 1). The fjord-valleys display glacier-margin features from glacier retreat in addition to numerous traces of mass-wasting activity (e.g., Hansen et al., 2009; Hjelstuen et al., 2009; Burki et al., 2010; Lyså et al., 2010). Lovatnet has been the scene of major, devastating rock failures and associated tsunami events in historical times. The most well-known disasters happened in 1905 and 1936 causing a total of 134 casualties (e.g., Reusch, 1907; Holmsen, 1936; Nesdal, 2002; Furseth, 2006). Recent research projects have aimed to study the landscape development and sediment transport history following the last deglaciation. In this context, bathymetrical and seismic surveys were carried out on Lovatnet in
2005-2006 and 2010. These datasets provide a basis for studying the morphology and sediment distribution in Lovatnet.

The aim of the present study is to reveal the morphology of Lovatnet with emphasis on past mass-wasting activity and deltaic processes based on a high-resolution bathymetrical dataset acquired in 2005. The work focuses on morphological traces on slopes, the lake floor and fan deltas from both known and previously undocumented events. A detailed morphological map covering the entire lake is included. The study benefits from onshore LiDAR data which, when combined with selected seismic profiles, allow for a comprehensive interpretation of the observed morphologies.

\section{Setting}

Lovatnet is situated in the innermost part of the Nordfjord area in western Norway (Fig. 1). The area is characterised by a mountain plateau deeply incised by fjords and valleys with an onshore relief of 1,500-1,800 m and mountain peaks up to $1,900 \mathrm{~m}$ a.s.l. Small ice caps, outlet glaciers and cirques characterise the high mountainous areas (Figs. 1,2). Bedrock is composed of granitic to dioritic gneiss and quartz monsonite (Lutro, 2003). 


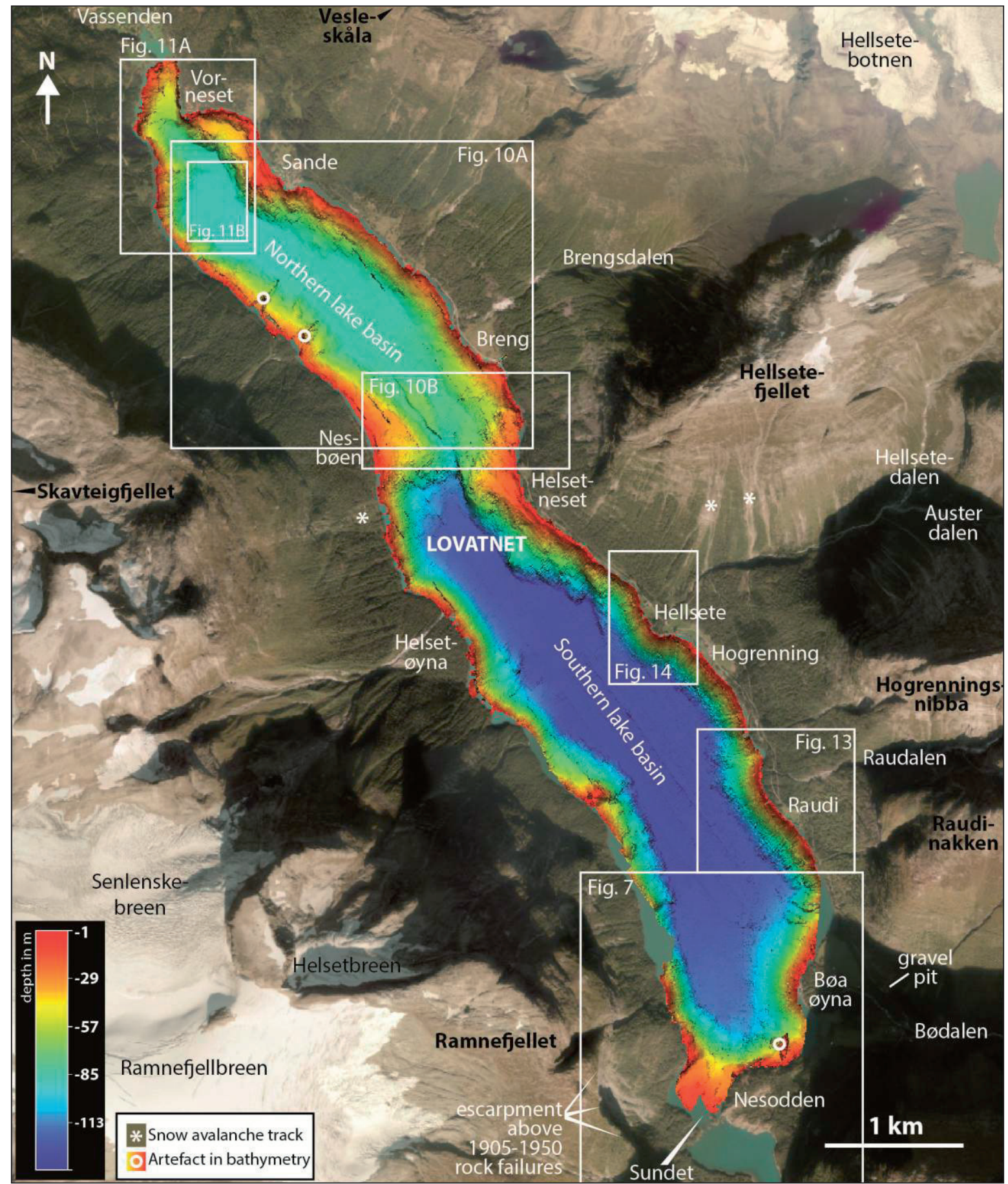

Figure 2. Overview over Lovatnet and surroundings based on the bathymetrical data and orthophoto from Norgeibilder.no. Location names and framed areas referring to figures are shown.

\section{Glacial history and landscape development}

Nordfjord is $c .100 \mathrm{~km}$ long and has been occupied repeatedly by glaciers during the Pleistocene. The mouth of Nordfjord was deglaciated following the last glacial maximum (LGM) at c. 14,250 cal. yr BP (calibrated from Larsen et al., 1984; Rye et al., 1987; Lyså et al., 2010). Several halts and readvances occurred during the Younger Dryas and the Preboreal during a general retreat pattern (Fig. 1; Mangerud et al., 1979; Fareth, 1987; Hjelstuen et al., 2009). Glaciers disappeared entirely between $c$. 7,200 and 6,100 cal. yr BP (e.g., Nesje et al., 2001). Subsequently, new glaciers were formed and reached a maximum extent between c. 2,200 cal. yr BP and AD 1750 (known as the 'Little Ice Age' interval (LIA); Bickerton \& Matthews, 1993). LIA moraines are present in several valleys including the catchment of Lovatnet (Fig. 1; Burki et al., 2009). The highest level of marine inundation after deglaciation at Loen is estimated as $\sim 86 \mathrm{~m}$ above present mean sea level (Fig. 1; Lien, 1985; Rye et al., 1997). 
Additional terraces located c. $100 \mathrm{~m}$ a.s.l. at the mouth of Bødalen (near the gravel pit in Fig. 2) have been suggested as glaciofluvial deltas deposited in a glacierconfined basin near the ancient sea level. Extrapolation of regional displacement data from north of Loen indicates an isolation of Lovatnet at around 10,000 cal. yr BP (Fig. 1; Svendsen \& Mangerud, 1987). The region has been affected by exceptional events such as the Storegga tsunami (Vasskog et al., 2013), and possibly major earthquake activity at around 2,000 cal yr BP (Bøe et al., 2004; Lyså et al., 2010).

\section{Physiography of Lovatnet and its catchment}

Lovatnet is up to $1.4 \mathrm{~km}$ wide, $c .11 \mathrm{~km}$ long and $130 \mathrm{~m}$ deep extending from a narrow lake arm at a fjord-head delta outside the Kjenndalen valley in the south to Vassenden in the northwest (Figs. 1, 2). The water level is 52 $\mathrm{m}$ a.s.1.. The narrowest part of Lovatnet, named Sundet, is located at the Nesodden bedrock constriction (Fig. 2). Here, there are small-sized islands of debris from the rock-failure events at Ramnefjellet. Lovatnet is surrounded by steep bedrock slopes (Figs. 2, 3). Tributary
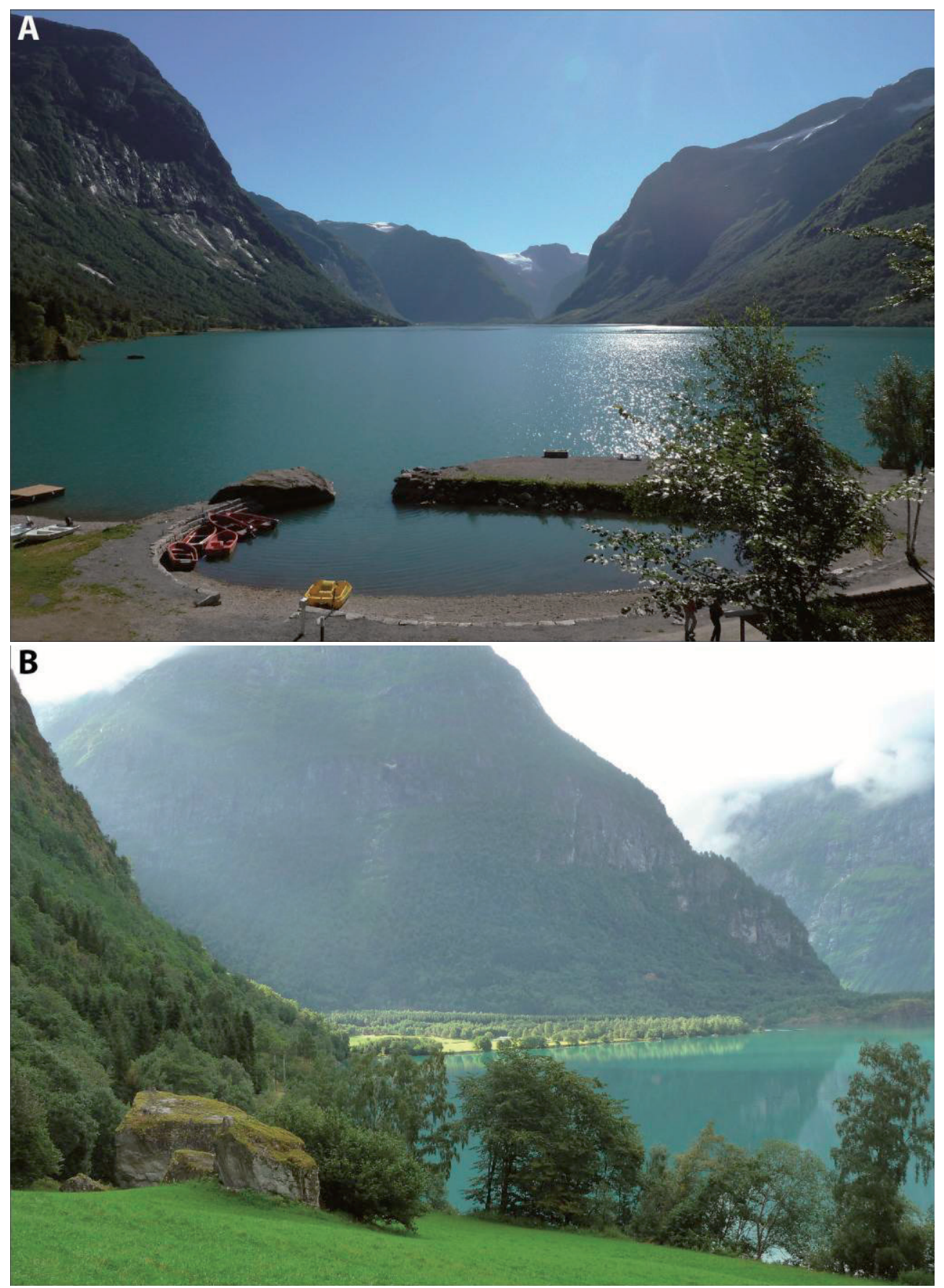

Figure 3. (A) View from Sande towards the southeast along Lovatnet. The prominent Hellsetefjellet is shown to the left whereas Ramnefjellet is shown in the middleground to the right. In the background is the Krunebreen outlet glacier from the Jostedalsbreen ice field. (B) View from Raudi towards Bøaøyna (Bødals delta). The huge blocks in the foreground are from the rockfall at Raudi in 1885; see text. Photos: Louise Hansen. 


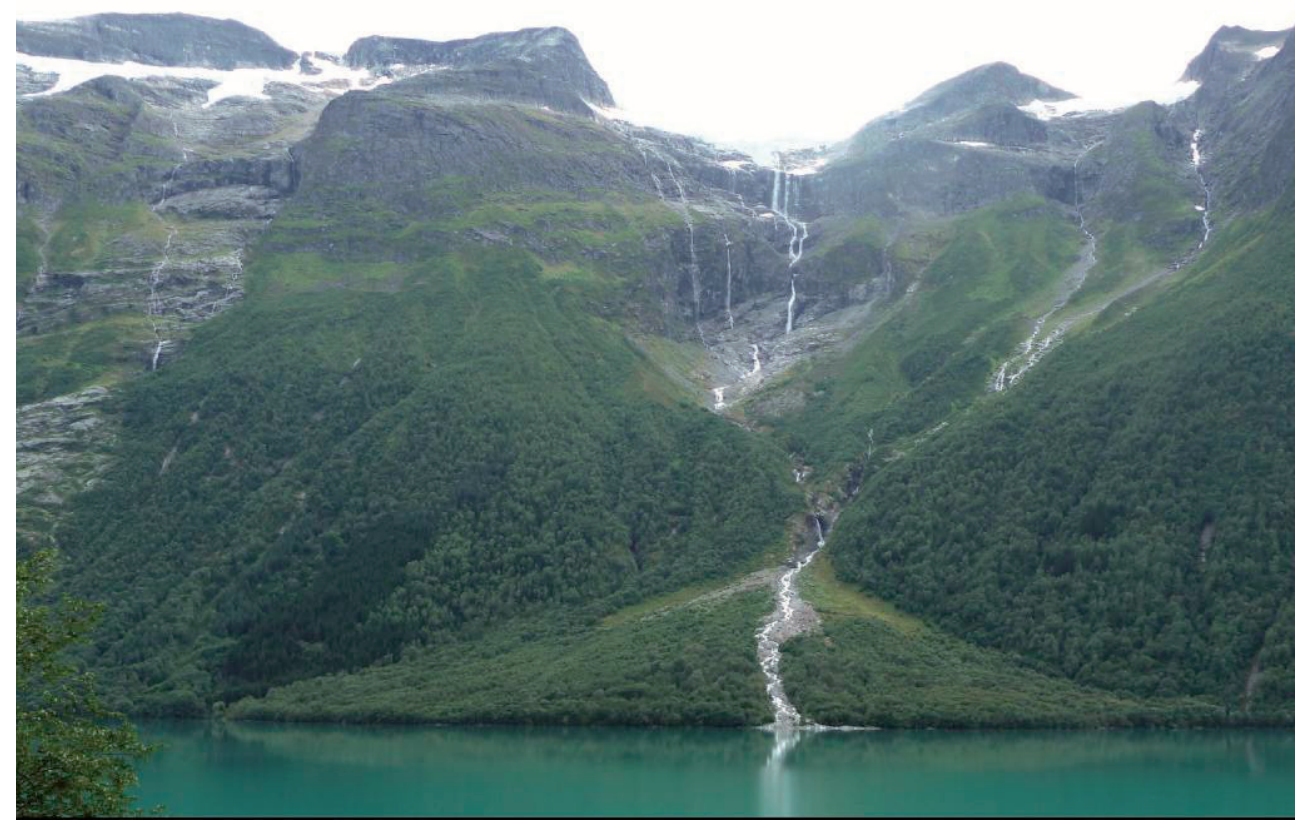

Figure 4. View towards Helsetøyna (Helset fan delta) and its catchment with steep bedrock slopes and glaciers. Notice the treeless apex of the fan, which is otherwise densely vegetated with just one active fluvial channel. The water in Lovatnet is bluish in colour during the summer season due to the supply of meltwater. Photo: Louise Hansen.

valleys and steep streams cascade into the lake either directly or via steep fans e.g., at Helsetøyna and the Helset delta (Figs. 2, 4). The Bødalselv river feeds a major, low-angle delta at Bøaøya in the southeastern part of Lovatnet (Bødalsdelta; Fig. 3B). The outlet of Lovatnet at Vassenden drains into Lobukta, one of the innermost arms of the Nordfjorden fjord system near the village of Loen (Fig. 1).

\section{The historical Lovatnet landslide disasters}

Some of Norway's most well-known and devastating rock fall, rock avalanche and tsunami events occurred in 1905 and 1936 at Ramnefjellet (Fig. 5). They caused a total of 134 casualties (61 and 73, respectively) and severe destruction of houses and farm land. There have also been other fatal and destructive events along Lovatnet. For example, snow avalanches destroyed settlements at Breng and Hellsete in 1500 and 1755, respectively (Furseth, 2006). Landslides, likely rock falls, hit the settlements at Raudi in 1614 and 1743, and a destructive rock fall from Kvithammaren on the $2^{\text {nd }}$ of March 1885 resulted in the abandonment of the settlement at Raudi (Furseth, 2006).

The 1905 disaster happened on January $15^{\text {th }}$ when a total of $350.000 \mathrm{~m}^{3}$ of rock, talus and glacial debris slid into Lovatnet (Helland, 1905; Reusch, 1907). The rock fall took place at Ramnefjellet from a height of $c .400-500 \mathrm{~m}$ (Bjerrum \& Jørstad, 1968; Furseth, 2006). The reported impact wave had a maximum height of $40.5 \mathrm{~m}$ over
Nesodden reaching $14.5 \mathrm{~m}$ and 15.5 at settlements on the Bødalsdelta to the northeast and the Nesdalsdelta to the south, respectively (Reusch, 1907). A strip of land along the shoreline of the Nesdalsdelta disappeared (Nesdal, 2002). The wave affected the whole lake and reached a height of $5.8 \mathrm{~m}$ at the outlet causing the destruction of a bridge (Nesdal, 2002). A number of subsequent rock falls occurred in the following months (Bjerrum \& Jørstad, 1968). The depth of Sundet was measured after the 1905 disaster which led to an estimated vertical infill of the lake floor by $5.5 \mathrm{~m}$ over an area of $250 \times 250 \mathrm{~m}^{2}$ (Reusch, 1907).

The 1936 disaster happened on September $13^{\text {th }}$ and was even more dramatic. A rock mass of more than 1 million $\mathrm{m}^{3}$ was released from a height of $800 \mathrm{~m}$. The impact wave at Nesodden reached a height of $74.2 \mathrm{~m}$ (Holmsen, 1936; Bjerrum \& Jørstad, 1968; Furseth, 2006). The wave heights reached over $20 \mathrm{~m}$ at the two settlements at Nesdal and Bødal and $15 \mathrm{~m}$ near the lake's outlet at Vassenden (Bjerrum \& Jørstad, 1968; Jørstad, 1968; Furseth, 2006). After the first wave had passed, the lake bottom at Vassenden was exposed for 200-300 metres before the second wave arrived. This wave took away all houses, the bridge and the local steamboat Lodølen (Nesdal, 2002). There were three high waves in total, but the wave movement continued the whole day indicating a seiche effect. The waves destroyed a total of $c .100$ houses around the lake in addition to bridges and boats (including Bødal). The onshore shipwreck Lodalen from the 1905 disaster was moved an additional $150 \mathrm{~m}$ and is currently located $50 \mathrm{~m}$ above the lake surface (Nesdal, 2002). In addition, 
a strip of land along the shoreline of the Bødalsdelta facing Ramnefjellet had disappeared (Nesdal, 2002). There were several additional rock failures and impact waves that followed shortly after. One of these involved even more rock volume and locally higher impact waves than described for the main event. No lives were lost, however, but boats and the new bridge were destroyed. The sound between Nesodden and the rock-fall site was progressively being filled with rock debris during the 1936 event. Detailed maps of Lovatnet, with information on wave heights, maximum wave flooding and wave propagation velocities during the 1905 and 1936 events have been presented by Bjerrum \& Jørstad (1968), Jørstad (1968) and Nesdal (2002).
A third event occurred in May 1950 when $>500,000 \mathrm{~m}^{3}$ of rock mass fell into Lovatnet from Ramnefjellet leading to a further loss of property. The wave at Vassenden reached 7-8 $\mathrm{m}$ in height, destroyed a road, several boats and again the bridge. However, no lives were lost as the settlements were not re-established after the 1936 events (Furseth, 2006). Sundet was nearly filled with rock debris during the 1950 event (Nesdal, 2002) permitting the passage only to boats with a shallow hull. A total of 3 million $\mathrm{m}^{3}$ of rock mass was released from Ramnefjellet between 1905 and 1950 (Grimstad \& Nesdal, 1990). High water pressure in bedrock fractures is anticipated to have been a trigger for the events (Grimstad \& Nesdal, 1990; Grimstad, 2005). Lake Lovatnet has already shown its hazard

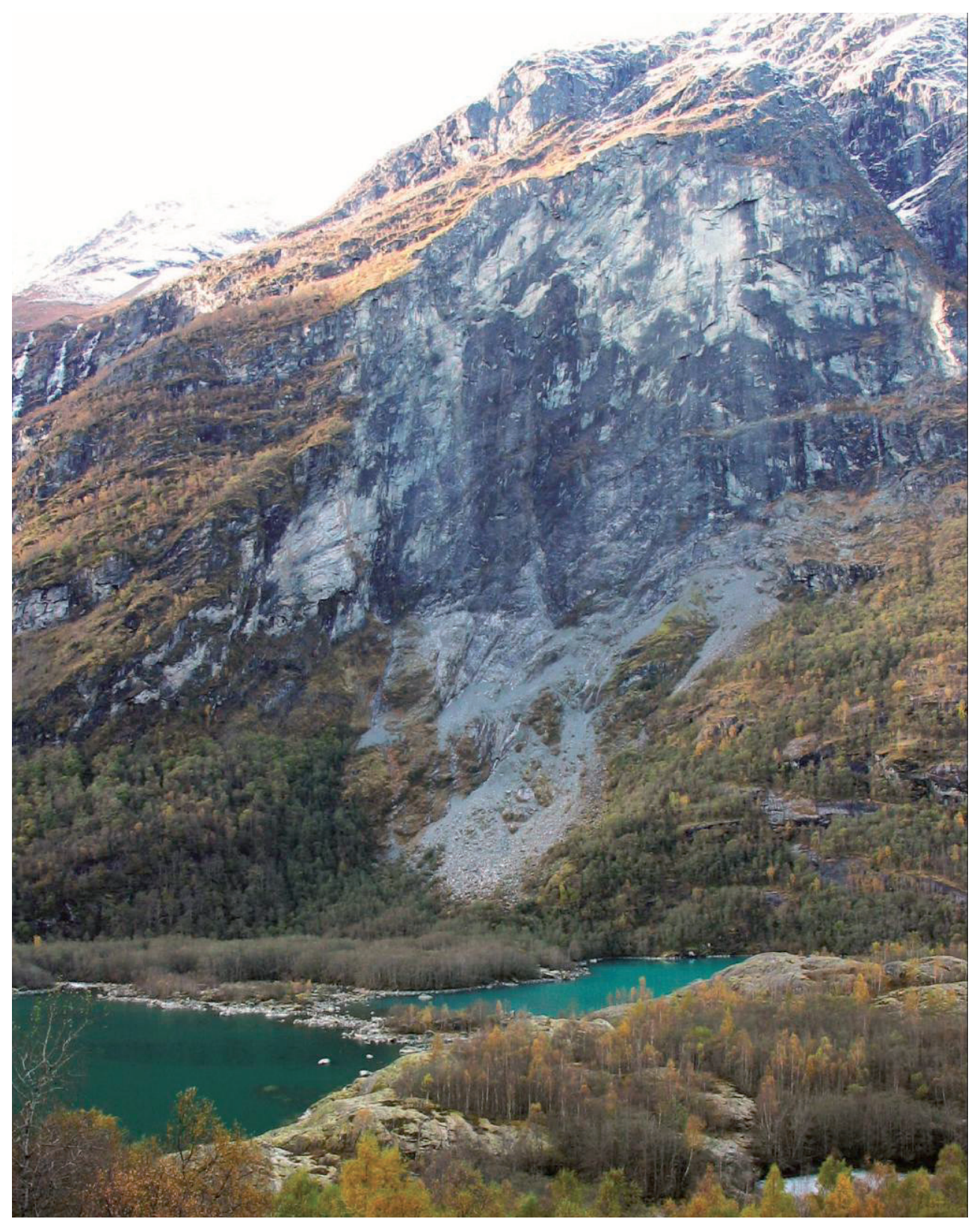

Figure 5. View toward the Ramnefjellet rock wall that was the source of the disastrous, historical, rock failures. Notice the landslide debris in the lake that almost fills Sundet between the Ramnefjellet slopes and Nesodden in the foreground. Photo: Louise Hansen. 
potential and is still considered tsunamigenic (Romstad et al., 2009). Fortunately, tsunami hazard levels have been reduced due to debris filling the lake below Ramnefjellet, as well as risk levels as settlements have either been abandoned or re-established at higher elevations. A webbased overview of all known historical landslide events affecting roads and settlements around Lovatnet and Oppstrynsvatnet is given at http://atlas.nve.no.

\section{Methods}

High-resolution bathymetric data were collected in 2005 using a $125 \mathrm{kHz}$ GeoSwath interferometric side-scan sonar from GeoAcoustics that was mounted on a locally rented boat. Data were collected at a speed of around 4 knots and with a general line spacing of $c .100 \mathrm{~m}$. Sound velocity profiles (SVP) were measured using a Valeport 650 SVP. The water level during the survey was measured digitally using a submerged Valeport 740 instrument. A base station was used for a positioning on a dm scale (RTK) and a gyroscope was used to adjust navigation. In locations with poor signal coverage, primarily due to the high relief, a differential GPS was used for positioning, giving an accuracy of \pm $1 \mathrm{~m}$. Processing was conducted using the GeoSwath software and included sound velocity correction, calibration (to reduce signal-to-noise ratios) and adjustment of the position between profiles. Data amalgamation and calculation of a $1 \mathrm{~m}$ grid was also carried out in the GeoSwath software. Backscatter data were extracted giving rough estimates on sediment types. High backscatter values are indicative of a firm substratum whereas low values indicate a dominance of soft and fine sediments.

A seismic survey in Lovatnet and other lakes was conducted in 2006, using a single-channel high-resolution GeoAcoustic 3.5-kHz pinger with an Octopus acquisition unit, both provided by the Geological Institute of ETH Zurich. A $1 \mathrm{in}^{3}$ airgun multi-channel system property of the University of Geneva was applied simultaneously. Pinger profiles were recorded in SEG-Y format and processed using band-pass filtering $(2-6 \mathrm{kHz})$ and Automatic Gain Control (100-ms window length). A water bottom mute was applied and constant shallow noise was digitally removed. An additional seismic survey was carried out in 2010 using a parametric echosounder (PES light developed by Innomar Technologies $\mathrm{GmbH}$ ). The frequency ranges between 4 and $15 \mathrm{kHz}$ are sufficiently low to penetrate the lake bottom sediments while the primary-frequency signals (about $100 \mathrm{kHz}$ ) can be used to determine the water depth. The geophysical data were interpreted using the dedicated ISE Post-processing software ISE.

Besides the geophysical methods described above, the catchment of Lovatnet has been studied on aerial photographs and in field reconnaissance. A DEM with a resolution of $1 \mathrm{~m}$ was constructed based on LiDAR data from 2013, which has been combined with the lake bathyme- try data. LiDAR data help to obtain a detailed view of the terrain, even where the land surface is covered by vegetation. Shaded reliefs of the combined datasets were analysed in ERDAS ERmapper and ArcGIS by ESRI.

\section{Results and interpretation}

We first characterise the landscape surrounding Lovatnet, followed by a description and interpretation of the Lovatnet lake bathymetry (Fig. 6).

\section{Onshore slopes and tributaries of Lovatnet}

The landscape around Lovatnet varies from local, lowangle, debris-covered surfaces to vast vertical bedrock walls. Bedrock exposures on the slopes are fairly common and are shown by sharp-edged structures on the LiDAR data (e.g., Fig. 7). Debris-covered slopes appear as smooth, undulating surfaces in places with well-defined fans and lobes. Stream-cut ravines commonly dissect the debris-covered slopes. The lobes vary in size from small, tongue-shaped features to $300 \mathrm{~m}$-wide, blocky patches. The surface roughness from LiDAR gives an indication of boulder size and abundance. Major, blocky patches are present, e.g. below Hellsetefjellet and above Sande. Single boulders up to $20 \mathrm{~m}$ across are registered locally.

Gravitational processes are responsible for much of the debris on the slopes. Sources are local bedrock likely combined with reworked glacially derived material. Smooth, fan-shaped features with scattered boulders are from snow-avalanche and rock-fall activity. Down-slope treeless corridors on steep slopes are snow-avalanche tracks (Figs. $2 \& 4$ ). An avalanche protection wall is present at Hellsete. Shallow channel features, some with levees, are locally present on the lower slopes. These channels and associated tongues or lobes were formed by debris flows or slush flows. Marked patches with landslide debris and major boulders are associated with larger rock-fall events.

Glacial deposits are locally recognised on LiDAR data as undulating surfaces in low-angle terrain in accordance with general map information (Klakegg et al., 1989; Fig. 6). Glaciofluvial deposits with delta foresets, covered by rock-fall debris, are exposed in a gravel pit north of the Bødalsdelta at Bøaøyna (Fig. 2). The deposits occur in a terrace around 100 m a.s.l. (Lien, 1985, Rye et al., 1997). Several alluvial and colluvial fans have been constructed around Lovatnet and form distinct deltas as described below.

\section{The Lovatnet lake basin}

Lovatnet comprises two lake basins with near-horizontal lake floors separated by a threshold (Figs. 2, 6). The 


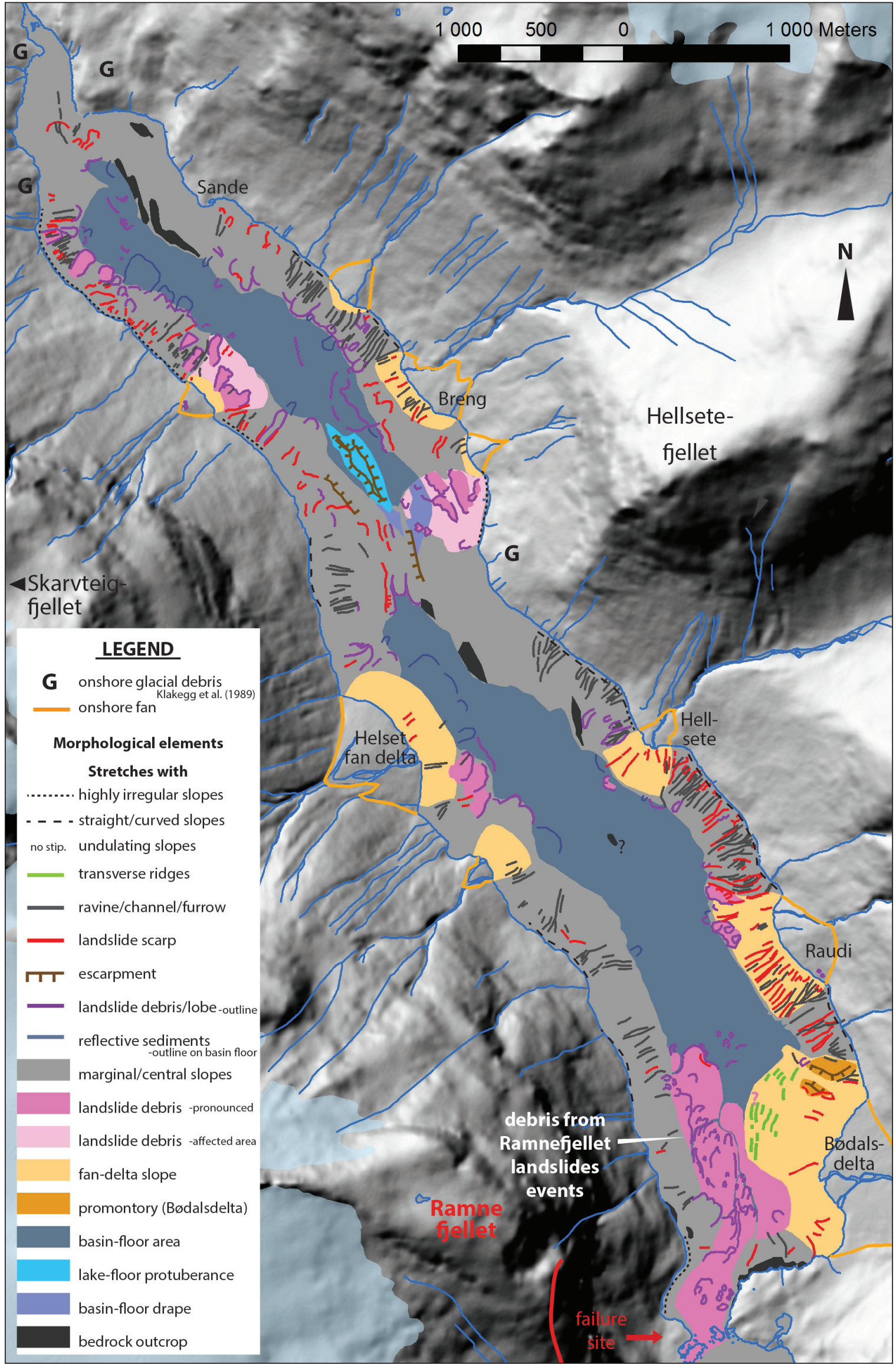

Figure 6. Map over Lovatnet with interpreted bathymetry. Classification of elements generally follows the scheme proposed for fjord marine settings by Hansen et al. (2013). 


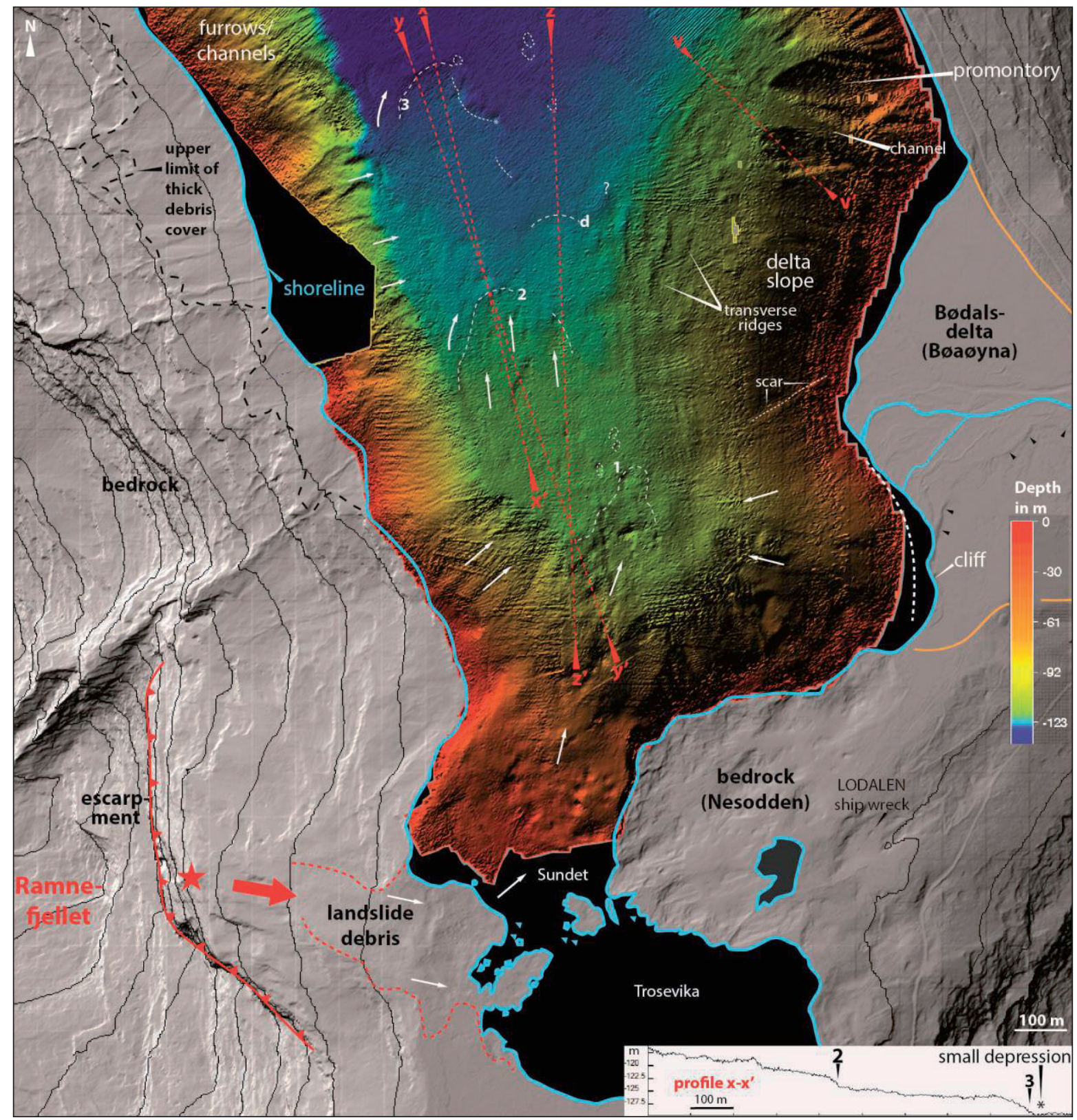

Figure 7. Bathymetry of Lovatnet between Ramnefjellet and the Bødalsdelta together with surrounding land areas (LiDAR). The onshore contour interval is $100 \mathrm{~m}$ (black lines) and the lowermost contour is $100 \mathrm{~m}$ a.s.l. The red star and red arrow show the source area for the Lovatnet rock-fall events. White arrows in the lake represent the inferred direction of debris movement. The three main debris lobes area numbered 1-3. The lobe marked with a ' $d$ ' is possibly of deltaic origin. Question mark, see Fig. 8. $x-x^{\prime}$ shows the location of the inserted profile transect. $y-y^{\prime}, z-z$ ' and $v-v^{\prime}$ show the locations of seismic profiles shown in Figs. 9 and 15.

northern and southern basins are down to $90 \mathrm{~m}$ and 130 $\mathrm{m}$ deep, respectively.

Southern basin plain with major debris lobes

The southern basin plain is smooth locally with a gentle incline along its margin. Major debris lobes are present to the south (Fig. 7). The debris can be followed to Sundet below the landslide site at Ramnefjellet (Fig. 5). The entire deposit extends $c .1 .8 \mathrm{~km}$ northwards along the lake floor including $1 \mathrm{~km}$ on the basin floor plain. The extent of debris to the south of Sundet is unknown. The landslide debris is bounded by steep, marginal slopes to the west and fades out towards the toe of the
Bødalen delta slope to the east. Although transitions are somewhat diffuse it is possible to roughly divide the debris into three main lobes (Figs. 6, 7). A more diffuse debris lobe is present farther to the east between the main lobes and the Bødalsdelta and is marked with a 'd' in Figs. 7 and 8. Some elongated, diffuse features are also indicated. The southernmost lobe (lobe 1) extends from shallow water and more than $900 \mathrm{~m}$ northwards. The width is about $200 \mathrm{~m}$ where the slope angle is reduced at the foot of the subaqueous slope. The overall slope angle varies from a few to over 20 degrees. The lobe has a relief of up to $8 \mathrm{~m}$ and has an irregular, undulating surface with numerous 'humps' up to $5 \mathrm{~m}$ high. The middle lobe (lobe 


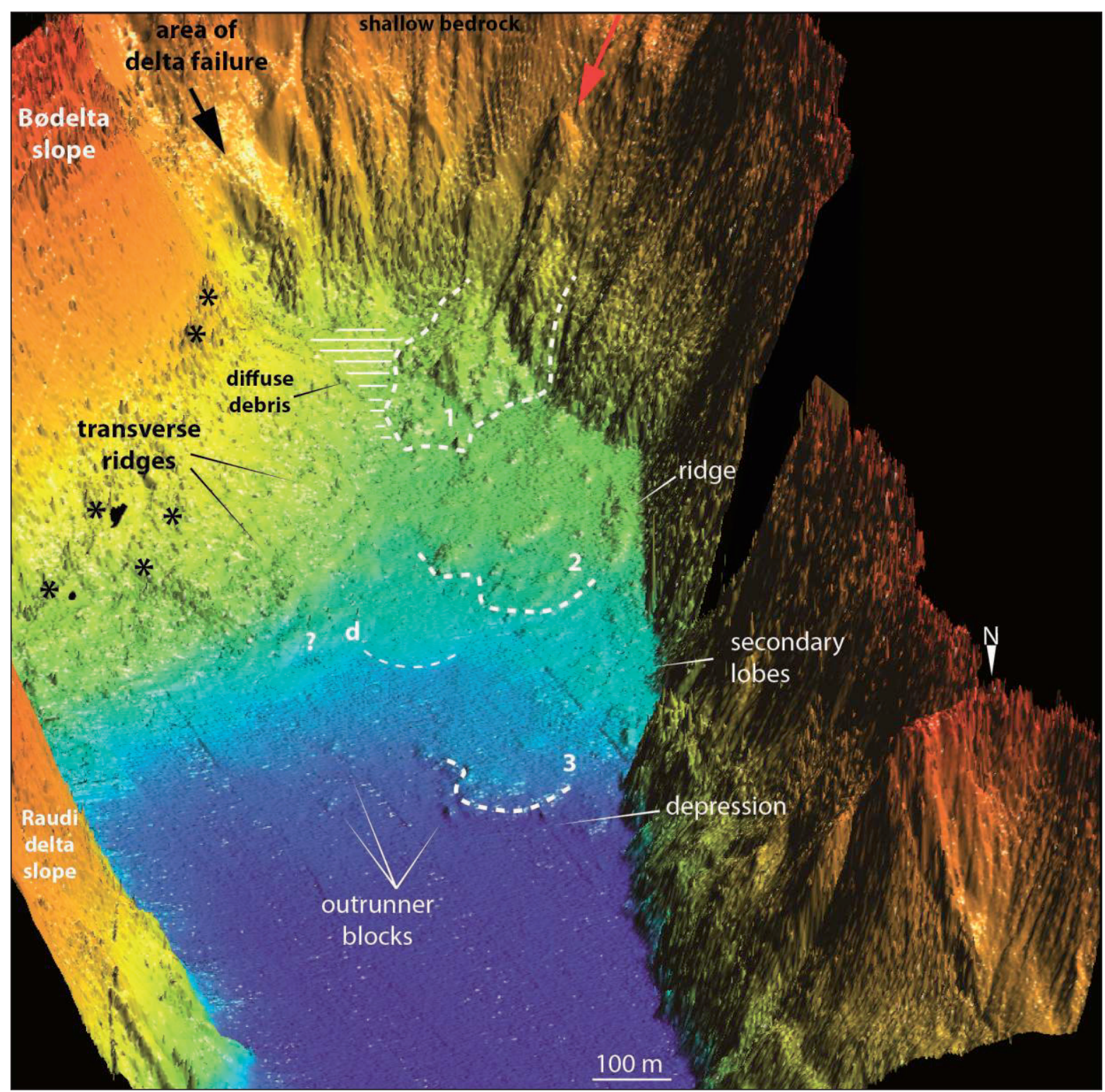

Figure 8. 3D view towards the south over the Ramnefjellet rock-fall debris along the bottom of Lovatnet. The question mark refers to diffuse, elongated features in the delta toe that could potentially represent additional and partially buried debris from Ramnefjellet. The colouring corresponds to the depth scale presented in Fig. 7. The height is exaggerated five times for improved visualisation. Areas dominated by artefacts are indicated by black asterisks.

2), located at the lake floor in deep water, is $c .450 \mathrm{~m}$ long, at least $300 \mathrm{~m}$ wide, and has an average thickness of $5 \mathrm{~m}$ over the basin plain level. The frontal relief is $2-3 \mathrm{~m}$ and the overall angle is only 0.5 degrees. Individual irregularities have typically a relief of $1 \mathrm{~m}$ and a few diffuse, superimposed tongues show a northward streamlining. A low ridge runs parallel to the western slope (Fig. 8). The northernmost lobe (lobe 3 ) is located at $130 \mathrm{~m}$ water depth and is $450 \mathrm{~m}$ long, up to $300 \mathrm{~m}$ wide and $c$. $4 \mathrm{~m}$ thick with a surface angle of less than 0.5 degrees. The debris surface has vague undulations with a relief of less than $1 \mathrm{~m}$. The debris is a few metres thicker along the western slopes with minor, secondary debris lobes (Fig. 8). The northernmost snout of the debris lobe is well defined. The lake floor just north of the northernmost debris snout displays a small depression and a broad, less than $0.5 \mathrm{~m}$-high mound farther north as also shown by seismics (Figs. 7, 8, 9A). The seismic profile shows that debris lobe 3 overlies and deforms the stratified lake sediments. These include debris overlain by a ponded, acoustically transparent interval representing an event bed as described from other lakes (Chapron et al., 1999; Schnellmann et al., 2006; Van Daele et al., 2015). The eastern part of the debris snout is crescentic-shaped with a steep edge (Fig. 7). A few outrunners are present to the east and the landslide debris fades out southeastwards towards the Bødalen delta slope (Fig. 7). Here, a seismic line helps to reveal the extent of the low, delta-derived debris lobe ('d'; Figs. 7, 8, 9B). The line also displays a secondary, surficial drape of debris from flows reaching out- 
side the main debris lobe. In addition, backscatter values indicate a drape of loose sediments. A rough estimate of the debris combining the volumes of lobes 2 and 3 above the lake floor level gives a volume of over 1.2 million $\mathrm{m}^{3}$.

The three debris lobes originate from repeated, major rock avalanches from Ramnefjellet combined with debris entrained from the adjacent slopes and lake floor (Figs. $7,8)$. The different appearances of the three lobes may be attributed to the dominating material entrained in the flow. Lobe 1, with its hummocky appearance, likely contains major rock fragments and is the youngest lobe. Lobe 2 probably consists of fragmented rock debris including mobilised colluvium and delta sediments. Lobe 3 is possibly dominated by with highly fragmented rock combined with remobilised colluvium and lake sediments, and is older than lobes 1 and 2. The crescentricshaped scar at the snout of lobe 3 reflects a local failure in loose, unstable debris. A trigger could have been traction caused by wave or seiche movement. Debris lobe ' $d$ ' is interpreted as consisting mainly of remobilised delta and lake sediments. It is not possible to clearly define the lobe southwards toward the area of delta failure but seismics give some information. A scar on the delta slope is indicated in Fig. 7. Lobe 'd' appears to be older than or of a similar age as lobe 2 . Some diffuse, elongated features at the toe of the Bødalsdelta could potentially represent additional buried landslide debris (Figs. 7, 8).

Backscatter data indicate a few, thin, high-reflective areas along the slopes, especially below the Helset fan delta (Fig. 6). These were generated by underflows and/ or sedimentation from local plumes. An additional, surprising feature in the middle of the southern basin plain is a distinct mound sticking up above the lake floor. It is $90 \mathrm{~m}$ long, almost $40 \mathrm{~m}$ wide and $5 \mathrm{~m}$ high (Fig. 6). Seismic data indicate that it has a root deep in the lake stratigraphy. This basin-floor feature could potentially be a bedrock outcrop in the extension of an interpreted bedrock ridge on the slopes to the north (Fig. 6). A glacial origin, or partially buried landslide material, cannot be excluded.

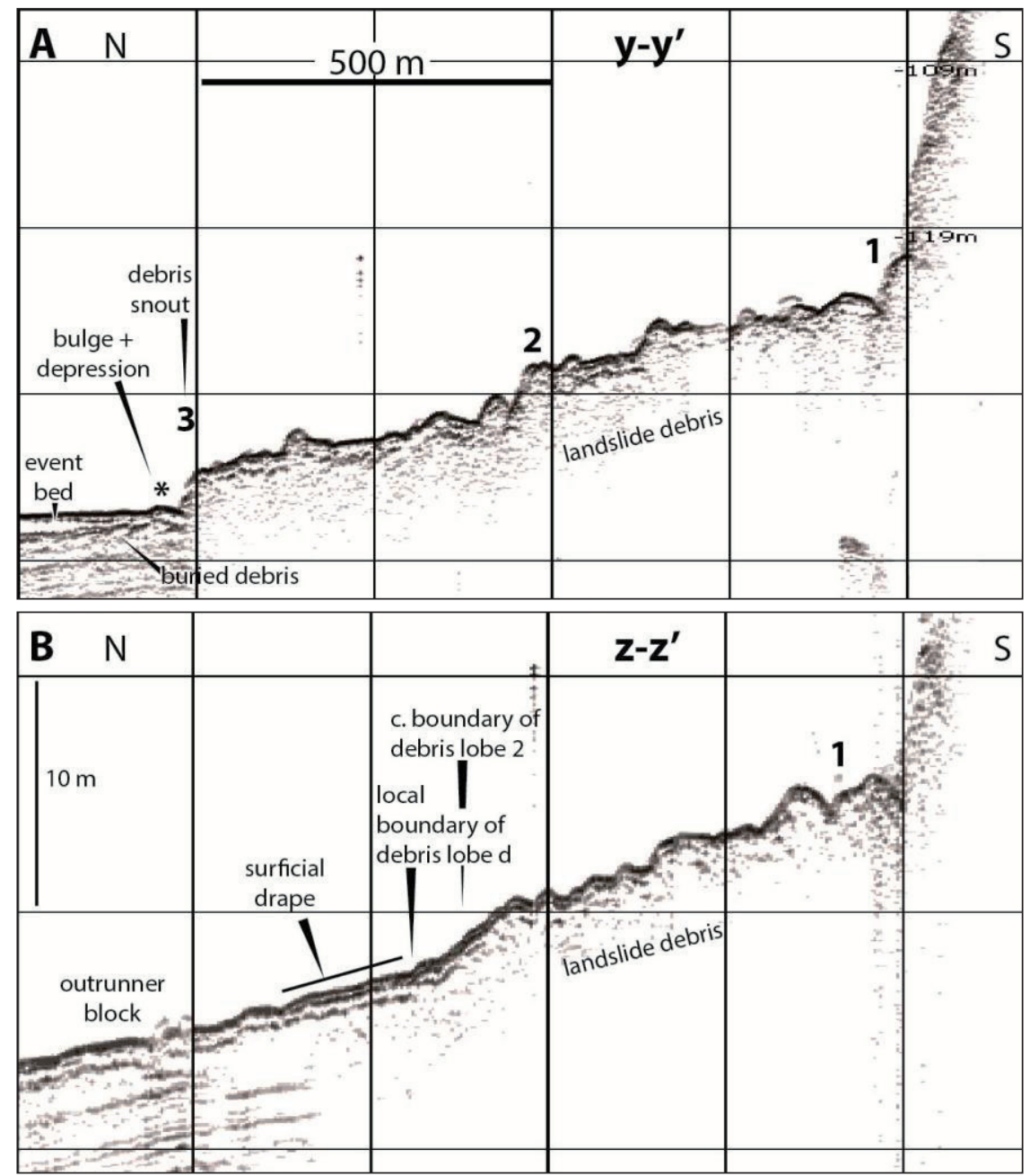

Figure 9. Seismic profiles crossing the Ramnefjellet landslide debris. See Fig. 7 for location of the profiles. (A) The three main lobes of the landslide debris are numbered. The asterisk shows a minor depression and bulge outside the main debris snout. Both are interpreted as having formed in association with the advancing lobe. This resulted in deformation of lake sediments including buried events beds (see text). (B) Lateral limitation of the debris lobe near the Bødalsdelta. 

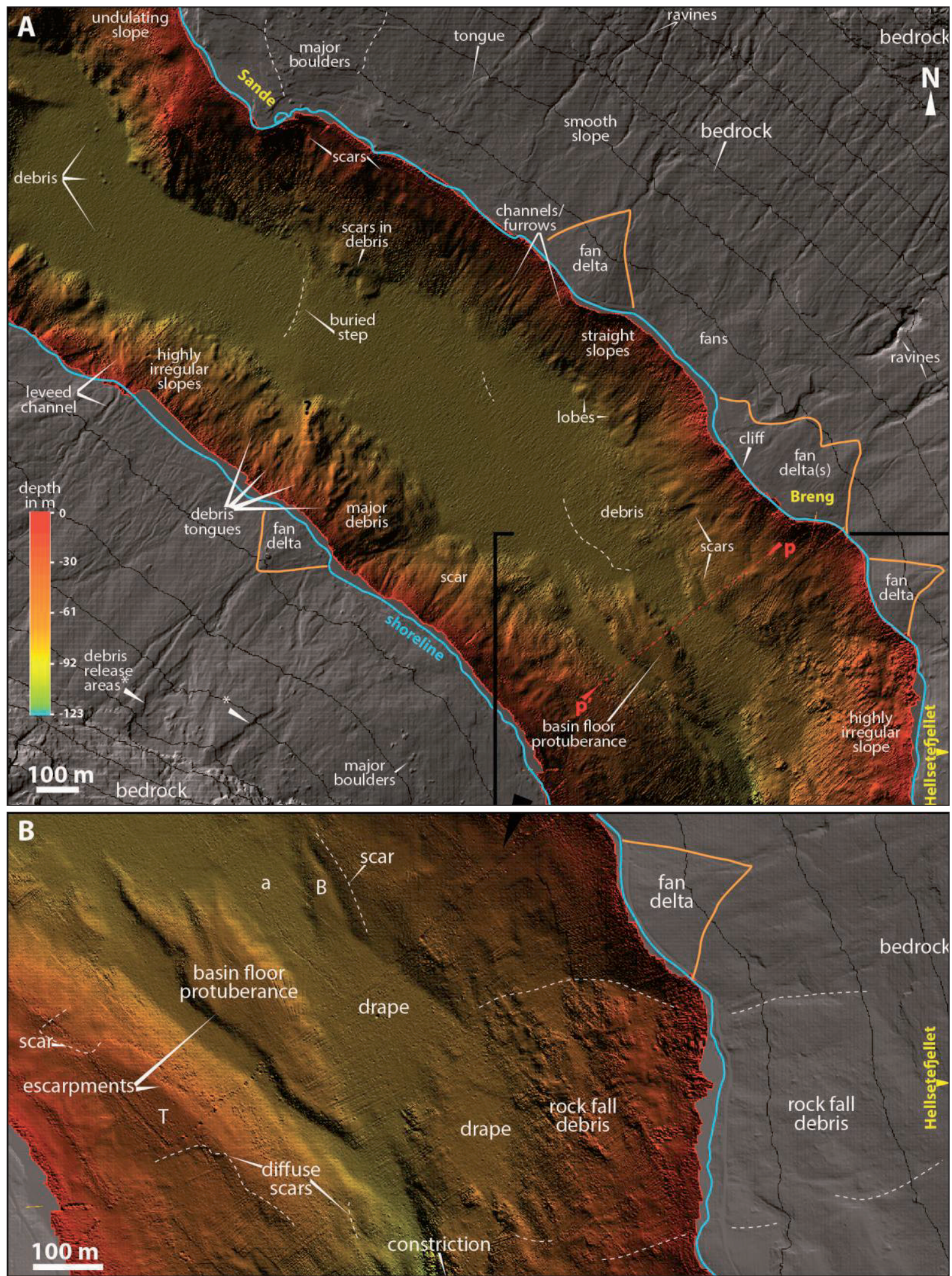

Figure 10. (A) Bathymetrical overview over the northern lake basin combined with onshore LiDAR data. The onshore contour interval is $100 \mathrm{~m}$ (black lines) and the lowermost contour is $100 \mathrm{~m}$ a.s.l. The location of seismic profile P-P' is also shown (Fig. 12). (B) Detail from the threshold area between the northern and the southern lake basin displaying the basin floor protuberance and major escarpments. 'T' represents a terracelike feature with an undisturbed drape of lake sediments. The arm ' $a$ ' of the northern basin plain shows a scar and a failed block 'B', which appears partially buried. A sediment sheet covers the toe of major rock-fall debris where the lake floor widens out in a southeastern direction. The debris below Hellsetefjellet shows individual 'humps' up to $25 \mathrm{~m}$ wide and $10 \mathrm{~m}$ in height, respectively, and represent major rock fragments. Big blocks are also visible above lake level. 
Northern basin plain

The floor of the northern lake basin displays superimposed, low-angle debris lobes west of the Breng fan delta (Figs. 6, 10A). The lobes are c. $250 \mathrm{~m}$ wide with a relief of up to $4 \mathrm{~m}$. As for the southern basin floor, backscatter data indicate a few, thin, high-reflective areas along the slopes (Fig. 6). Farther northwards, where the lake basin becomes narrower, the basin floor displays a marked, 1 $\mathrm{m}$ step down towards the deepest part of the northern lake basin (Fig. 10A). The step is considered to represent a buried sedimentological feature. The northern end of the basin floor displays an almost $400 \mathrm{~m}$-long array of minor lobe and debris features (Figs. 6, 10A, 11). Here, there are small, distinct mounds up to $3 \mathrm{~m}$ high and $15 \mathrm{~m}$ long surrounded by vague tracks and diffuse depressions. Upslope of the array are furrows that can be followed northwards almost to the northernmost tip of the dataset near Vassenden (Fig. 11A). These observations indicate that the debris mounds likely originated from near the outlet of Lovatnet, which implies transport of up to 1.5 $\mathrm{km}$ into the basin. A slim, $15 \mathrm{~m}$-long, $1 \mathrm{~m}$-high feature could potentially be the remains of the vessel Lodølen that disappeared during the 1936 event (Fig. 11B).
The mid-lake threshold

The mid-lake threshold between the northern and the southern basins displays a distinct, lake floor protuberance limited by escarpments (Fig. 10B). The feature has an undulating surface and is $c .460 \mathrm{~m}$ long, $100 \mathrm{~m}$ wide and $10-12 \mathrm{~m}$ high. It is bounded by channel-like features including a narrow arm of the northern basin floor displaying a partially buried landslide block ('B' in Fig. 10B). A seismic profile crossing the protuberance shows a cover of stratified sediments which also occur in the nearby lake floor arm (Fig. 12). The protuberance likely represents a buried, glacier marginal deposit or bedrock draped by hemipelagic fjord-lake sediments (Fig. 12). The bordering depressions could potentially represent buried subaqueous outwash channels as recorded in other fjords (e.g., Synnylvsfjorden; O. Longva, pers. comm., 2015).

A sediment sheet drapes the toe of irregular rock-fall debris below Hellsetefjellet (Fig. 10B). The sheet is interpreted as possibly the product of an expanding flow along the lake bottom. A constriction leading down towards the southeast into the southern lake basin is also identified. Here are low-relief lobes of debris and lateral edges interpreted as landslide scars (Fig. 6).

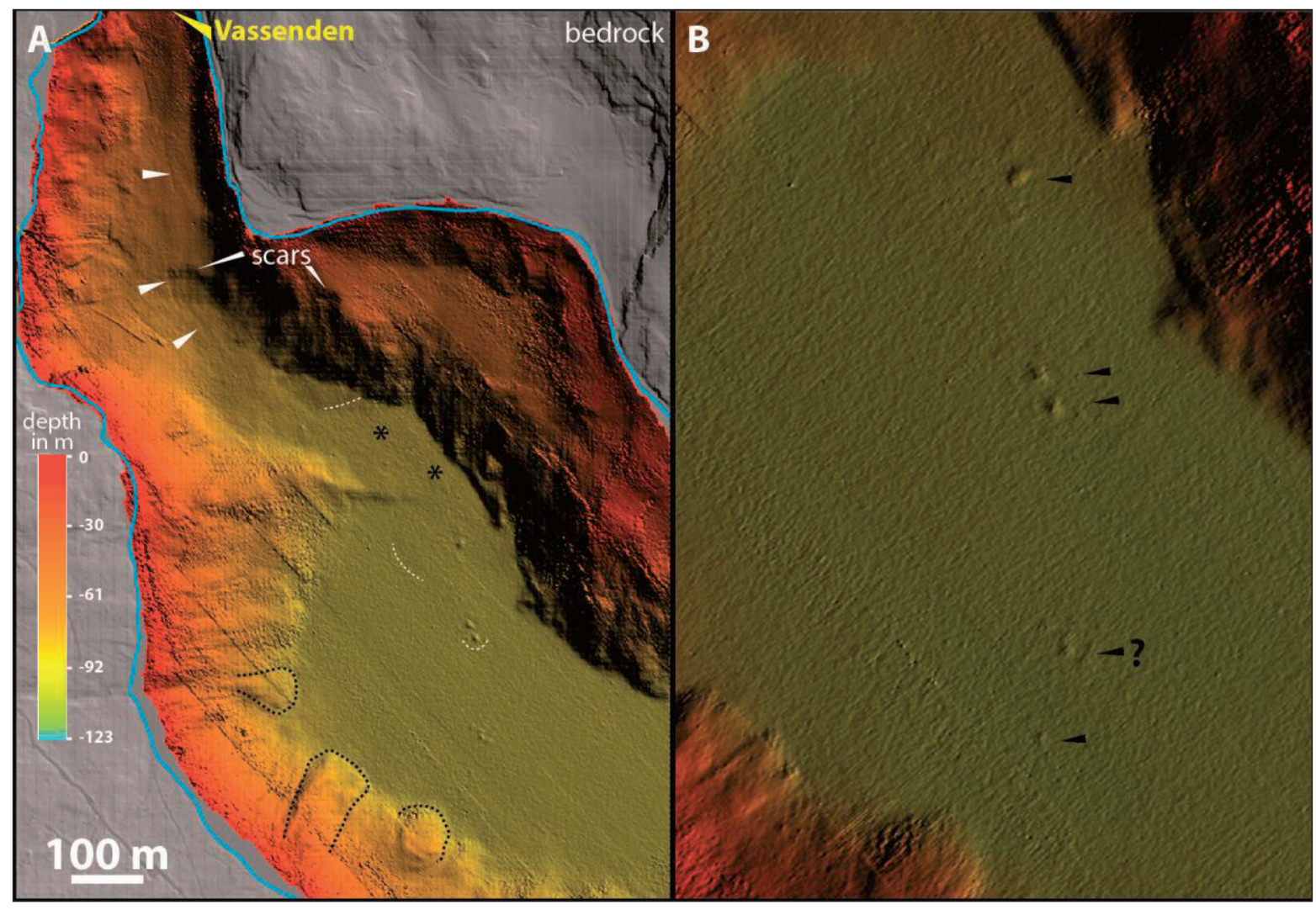

Figure 11. (A) Bathymetry in the northern end of Lovatnet. The white arrows show furrows that were formed during transport of debris along the lake bottom from Vassenden. Debris aprons are marked by black asterisks and the outlines of some low debris lobes are stippled in white. The outlines of some major lobe features on irregular slopes are stippled in black. (B) The black arrows show distinct debris mounds that were transported far into the northern lake basin, likely involving hydroplaning. The question mark indicates a long object that potentially could be the remains of the missing vessel 'Lodølen'. 


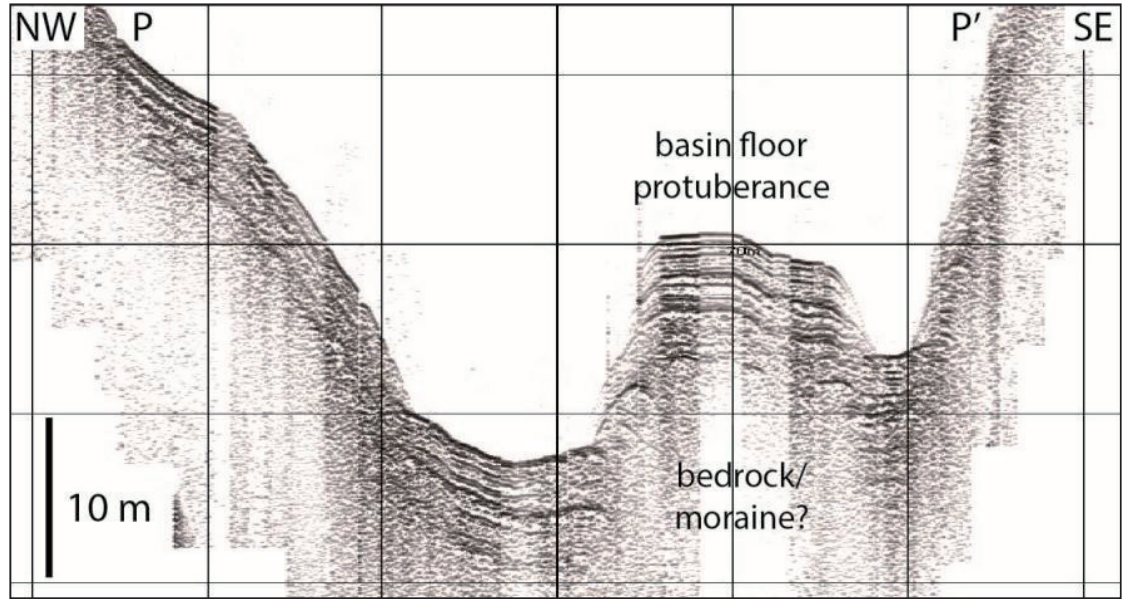

Figure 12. Seismic profile P-P' crossing the lake floor protuberance shown in Fig. 10. The stratified sediments on the protuberance could potentially be suitable for coring as they are generally outside the reach of gravitational processes.

\section{Fan deltas}

Most deltas surrounding Lovatnet are of the fan-delta type (Fig. 6). The steep onshore fan slopes indicate that they can generally be considered as colluvial sensu Blikra \& Nemec (1998). The distinct fan deltas are relatively small, composite and slightly irregular features. A notable exception is the voluminous fan delta at Helsetøyna (Helset delta; Fig. 4). The large Bødalsdelta is transitional to a normal delta and is described separately.

The onshore fan-delta plains typically have a slope of $15^{\circ}-20^{\circ}$ and display one main, active, distributary stream channel. Inactive channel features are common. Smooth surfaces are usually indicative of snow-avalanche activity as also shown by treeless corridors on the Helset fan apex (Fig. 4). Debris lobes and channels with levees are present locally, for example at Breng. These features are formed by debris flows or slush flows. Outsized boulders are common on the fan surfaces. As an extreme example, blocks 15 metres in size on the fan surface at Raudi are the result of a local rock fall that occurred in 1885 (Figs. $3 \mathrm{~B}, 13)$. The narrow plain of the Hellsete fan delta seems to be confined by snow-avalanche fans to the northwest and the possible remains of a glaciofluvial delta on the southeastern side (Fig. 14).

The fan-delta shorelines are close to their present-day delta fronts. The shape of the shorelines varies and differs locally from the theoretical, radial shape that may be expected from ideal fan-type deltas. The southern part of the Raudi fan-delta shoreline is relatively straight and extends parallel to the axis of the lake (Fig. 13). The southeastern part of the shoreline is characterised by a cliff up to $8 \mathrm{~m}$ high above lake level. A shallow subaqueous platform below the cliff can be followed lake-wards for several metres. Farther westwards, a small shoreline indention occurs above a shallow landslide scar on the delta slope (Fig. 13). The fan delta at Breng displays a cliff which is up to $5 \mathrm{~m}$ high (Fig. 10A). The abandoned part of the Hellsete glaciofluvial delta also displays a $>10$ m-high cliff with a minor, onshore platform at the base. The Helset delta front facing the lake appears straight, which could be the result of several stream sources combined with past failure activity. The shoreline of the smaller, remaining fan deltas also shows some variability, caused by multiple sediment sources, the presence of landslide debris and/or shallow bedrock topography.

The fan-delta slopes are relatively straight with angles varying from $20^{\circ}$ to $35^{\circ}$ and become slightly concave at the toe. They are generally smooth with local, shallow channel features and shallow scars (e.g., Figs. 6, 10A, 13). Smooth delta slopes are common for steep fan deltas affected by repeated, unconfined flows and/or suspension sedimentation (Prior \& Bornhold, 1990). Local channel features are interpreted as formed by undercurrents during hyperpycnal flood events (Mulder \& Chapron, 2011). Some features could represent chutes. Escarpments are formed by shallow deltaic failures due to oversteepening and/or wave activity. Backscatter values are relatively high as such steep systems are generally characterised by coarse debris (Postma, 1990). Some slopes display tracks with increased backscatter values reaching the basin floor and are likely tongues of coarse debris from recent, shallow failures. The fan-delta slope at Raudi differs from most other slopes by displaying numerous low-relief channel features and scars with varying backscatter values (Fig. 11). This indicates that deltaic undercurrents and minor failures have been active relatively recently. The delta slope at Breng shows relatively recent scars that are associated with debris on the basin floor (Fig. 6).

Several fan-delta slopes show special and pronounced features. The northern toe of the Raudi fan delta has protuberances that extend farther into the lake basin compared to the southern toe (Fig. 13). These protuberances have a clear, undulating appearance, and are interpreted as landslide debris that has been partially reworked and buried upslope by delta deposits. There is a relatively 


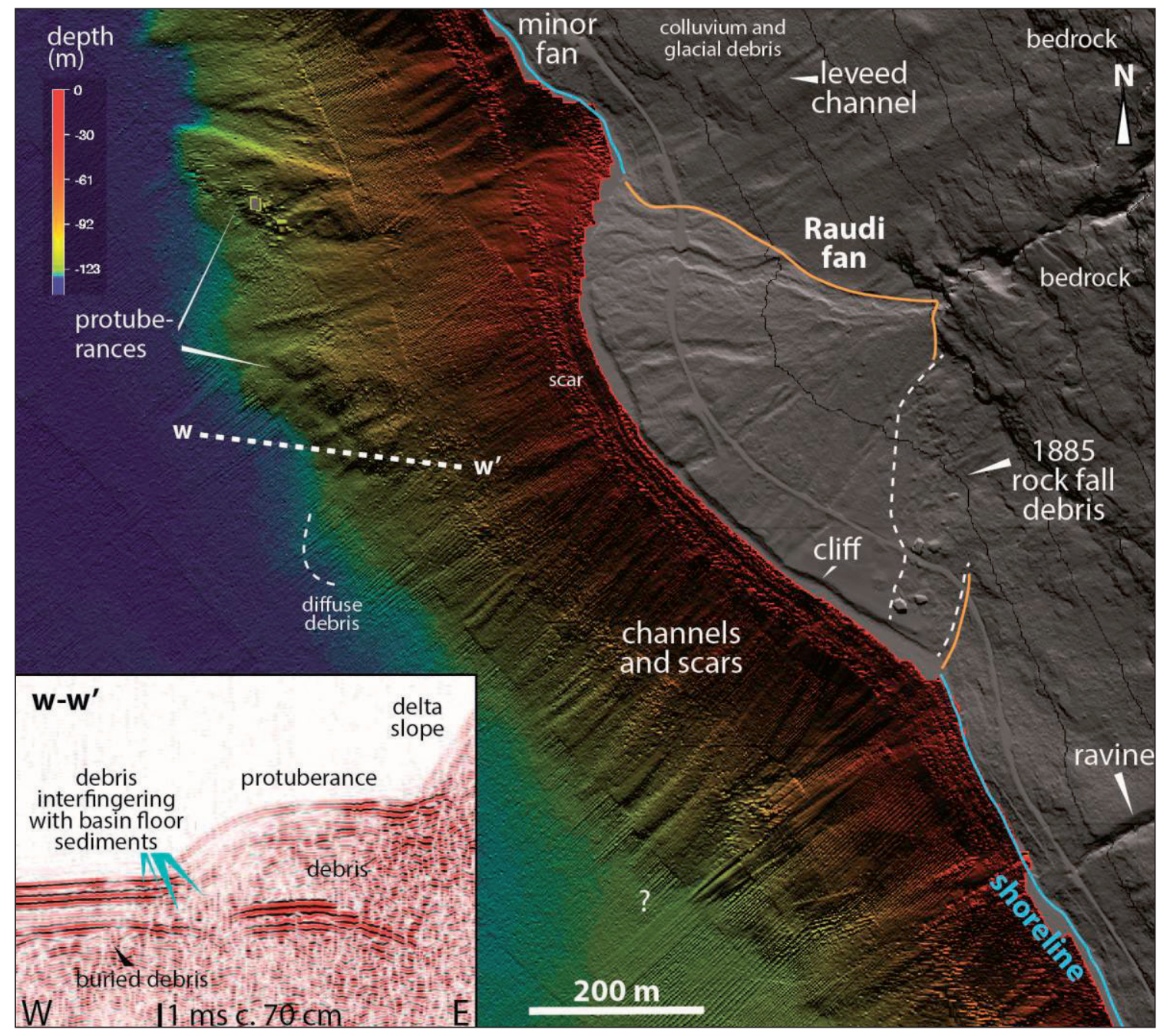

Figure 13. Bathymetry of the fan delta at Raudi with surrounding land areas (LiDAR). The onshore contour interval is $100 \mathrm{~m}$ (black lines) and the lowermost contour is $100 \mathrm{~m}$ a.s.l. The seismic line $w$-w' crossing the delta toe protuberance shows lenses of irregular debris that are pinching into the upper part of the lake stratigraphy, such that the protuberance is consequently of relatively young age. The rock-fall debris on the fan is from 1885.

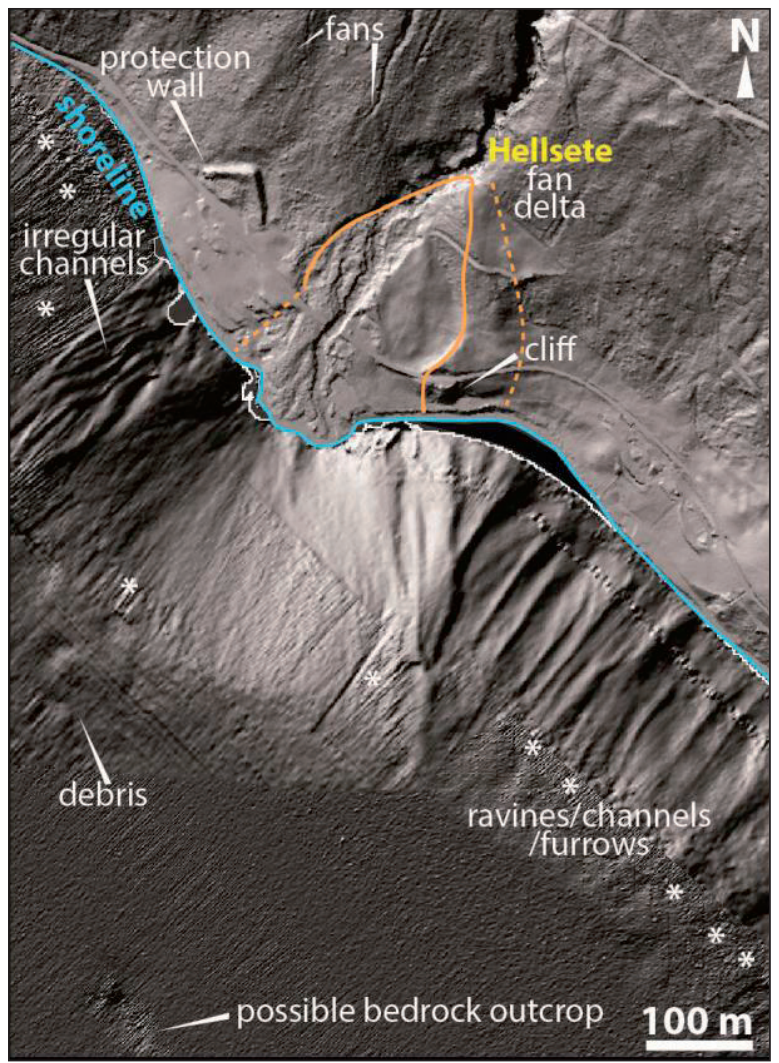

Figure 14. The present-day fan delta at Hellsete is outlined in yellow. The easternmost stippled line is interpreted as the outer limit of an older, now incised, glaciofluvial fan delta. Artefacts are indicated by white asterisks. The angle of illumination varies between land and lake bottom to optimise visualisation of both areas. 
sharp boundary between the protuberance and the basin floor that appears undisturbed. This indicates that basinfloor sediments cover the toe of the debris as supported by backscatter values. A seismic profile crossing the lobe shows that the debris interfingers with the uppermost lake sediments and is relatively young (Fig. 13). Pronounced and irregular accumulations of debris are found on the slope of a small fan delta below Skavteigfjellet, and draped accumulations are found at the toe of the Helset and Hellsete fan deltas (Figs. 6, 14). All the deltaic protuberances can be explained by mass-wasting in the deltas and/or their steep catchments followed by more regular delta sedimentation.

\section{Bødalsdelta}

The triangular Bødalsdelta differs from the other deltas by having an alluvial delta plain with an angle of only a few degrees. It has several channels whereof a few are active distributaries (Fig. 7). The main channel is confined by man-made levees to prevent flooding over farmed land. The present-day Bødalsdelta's shoreline is indented in its southern part (Fig. 7). This coincides with the part of the delta that disappeared during the disastrous landslide event in 1936. The onshore cliff is presently up to $5 \mathrm{~m}$ above the lake level. The northern part of the Bødalsdelta shoreline is relatively straight with just a few irregularities.

The Bødalsdelta slope is relatively smooth and has relatively low backscatter values except in front of the river's outlet. The angle of the slope varies from $30^{\circ}$ close to the river mouth to $10^{\circ}$ at the delta toe at $80 \mathrm{~m}$ depth. A few diffuse scars are present. One c. 2 m-high, distinct scar subparallel to the direction of slope is found close to the mouth of the main distributary channel (Fig. 7). The delta toe displays several, diffuse, transverse ridges a few metres high and with wavelengths of $c .40-50 \mathrm{~m}$ (Figs. 7, $8)$. The ridges disappear upslope where the delta slope is smoother, possibly reflecting a younger drape of deltaslope sediments. These elongated features are interpreted as buried ephemeral bedforms from flooding and/or landslide debris generated during mass-wasting (Figs. 8, 15).

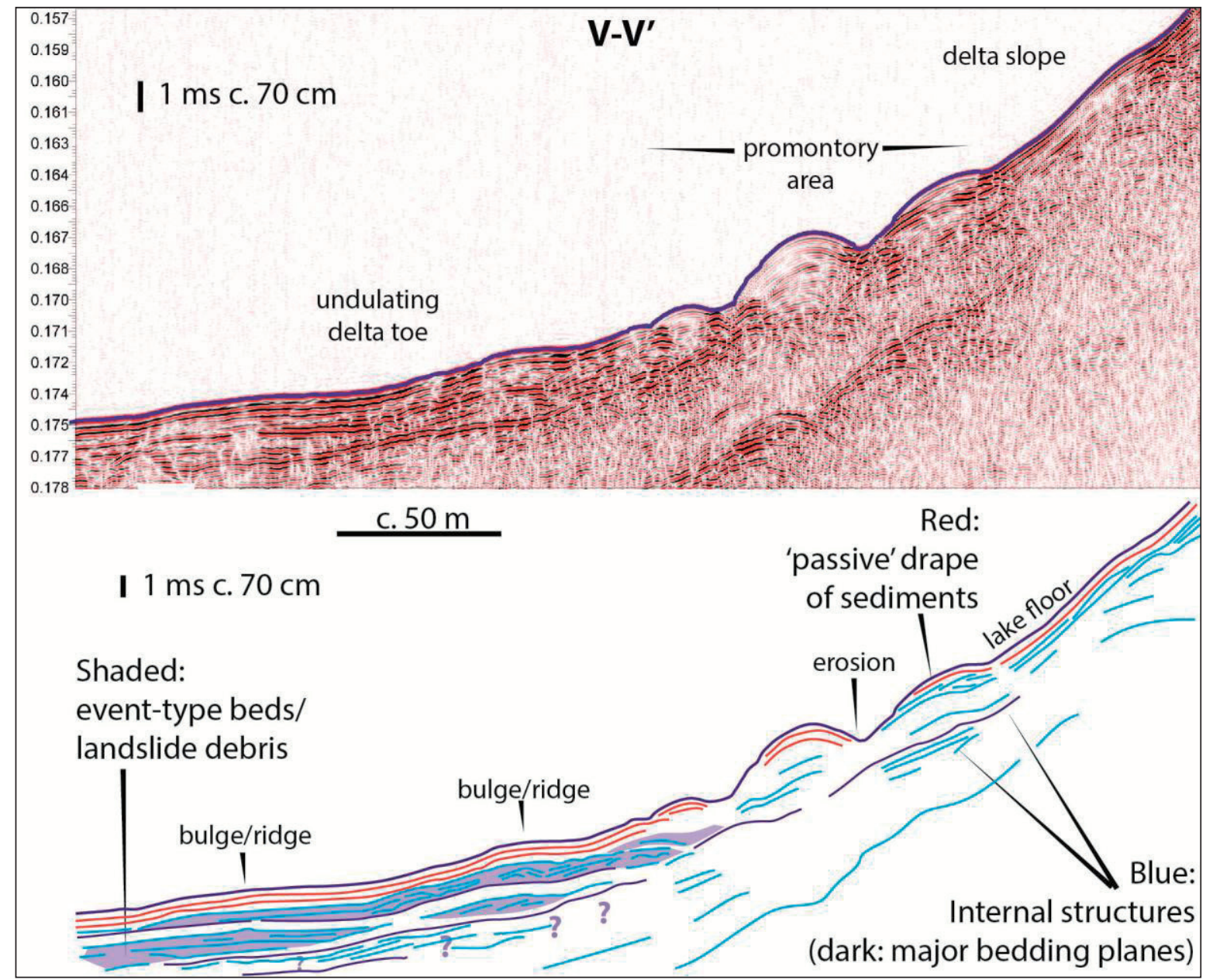

Figure 15. Seismic profile $V-V^{\prime}$ (on top) with interpretation (below) crossing the southwestern part of the promontory at the Bødalen delta shown in Fig. 7. The reflection pattern is highlighted in the lower panel. Notice how the event-bed lenses seem to control the sea-floor topography with bulges or ridges. The question marks show the inferred location of a possible deeper-lying event bed. The promontory seems to be associated with the younger part of the stratigraphy above the uppermost dark-blue reflections. The depth scale is in ms. 
The northernmost part of the Bødalsdelta slope is characterised by a major $250 \mathrm{~m}$-wide and $300 \mathrm{~m}$-long 'bulge' or 'promontory' incised by a major channel feature $90 \mathrm{~m}$ wide and up to $15 \mathrm{~m}$ deep (Figs. 6, 7). The promontory has a smooth surface indicating that it likely consists of deltaic sediments. A seismic profile crossing part of the promontory indicates a thin drape of overlying lake sediments (Fig. 15). The thin drape, the young stratigraphic position and well-preserved morphological appearance indicate a fairly recent formation (Fig. 15). The wavy lake bottom probably corresponds to transverse ridges observed at the delta toe, and may represent buried, lenticular, event-type beds (Fig. 15).

\section{Marginal and central slopes}

The marginal slopes show great morphological variability. The dominant slope types are marked along the shoreline in Fig. 6. Relatively straight to slightly curved slopes are dominated by steep ravines up to $5 \mathrm{~m}$ deep, narrow channels or furrows parallel to the slope, and minor lobes. Angles are 15 to 30 degrees. The start of some channels coincides with the mouths of onshore streams. Some channel features are associated with minor scars or edges at their upstream ends or parallel to the slope. Distinct or diffuse lobes/tongues with a low relief of a few metres are locally observed at the end of channel features. Lobes with more irregular channels are also locally present (Fig. 14). Undulating slopes have a diffuse, irregular to smooth appearance. Angles vary from a few to 70 degrees or more. A few scars and furrows are present. Steep, convex features are interpreted as exposed bedrock. These slopes are interpreted as consisting of glacial deposits or bedrock with a diffuse drape of colluvium or lake sediments. Highly irregular slopes are found at several places but especially below Skavteigfjellet (Fig. 6). These slopes are characterised by a combination of channel features, scars and distinct lobe features up to $100 \mathrm{~m}$ wide, $200 \mathrm{~m}$ long and $10 \mathrm{~m}$ high. Major boulder patches, e.g., west of Hellsetefjellet, are interpreted as landslide debris (Fig. 10B). Such patches are also present below Ramnefjellet (Figs. 6, 7). Backscatter values on the steeper slopes are generally high, reflecting coarse debris especially along the slopes to the west. Undulating slopes generally display lower values.

The slope deposits are generally interpreted as subaqueous colluvium and partially reworked glacially derived debris with or without a cover of lake sediments. The straight to slightly curved slopes indicate a cover of sediments with a thickness at least equal to channel or ravine depth. Channels originate from various flow processes such as undercurrents generated at the mouths of minor streams during meltwater and hyperpycnal flood events (Mulder \& Chapron, 2011). More concentrated flows (e.g., debris flows) started either onshore or in shallow water. Flows on the slopes locally entrained young sediments along the flow path creating slope-parallel scars. Furrows originating from sliding material may have formed locally. The lobe features on the irregular slopes are interpreted as landslide debris that likely involved rock-fall material, reworked colluvium and glacial debris. The steep rock faces above the lake were the source for large rock-slope failures that locally developed into rock avalanches reaching the basin floor such as below Ramnefjellet (Fig. 8). However, also at Hellsetefjellet a significant event seems to have happened sometime in the past (Fig. 10).

\section{Discussion}

The overall shape of the Lovatnet basin was carved primarily due to glacial erosion. However, glacial landforms are few and overprinted by younger, mainly gravitational processes and paraglacial activity. The midlake basin-floor protuberance could represent a buried glacier marginal feature as discussed above. Moreover, several fan-delta bodies likely accumulated during times of increased glacial discharge (e.g., the Bødalsdelta and the Helset delta). The abandoned part of the Hellsete delta is also considered to represent old glaciofluvial deposits. In general, delta plains were likely more active at times of high supply of glacial meltwater, such as during the LIA.

The morphological signatures associated with the Ramnefjellet events and with delta processes are described below. There are, however, numerous additional signatures of mass-wasting in and around the steep-sided Lovatnet basin (e.g., Fig. 6). These include the blocky debris below Hellsetefjellet and above Sande, thick irregular lobes below Skarvteigfjellet, and sedimentdraped debris at the base of some fan deltas. Advancing glaciers in the mountains around lake Lovatnet might have triggered a drop of glacial debris directly into the lake. Paraglacial conditions and climatic changes during the Holocene likely affected slope activity including rock falls, debris flows and snow avalanches as also reported from a neighbouring valley (Vasskog et al., 2011). Earthquake activity could potentially have played a role (Blikra et al., 2006). Despite the numerous traces of erosion and mass-wasting on the slopes and in the deltas, the basin floor appears smooth in many areas indicating that lake sediments have covered the debris.

\section{Morphological traces from the Ramnefjellet rock failures}

There are several morphological features in Lovatnet that can be attributed to the well-known rock avalanches, rock falls and tsunami events between 1905 and 1950 . The major debris lobes in southern Lovatnet are considered as originating from these events as indicated by their relatively 'fresh' morphological appearance (Fig. 8 ). The low backscatter values indicate a cover of suspended sediments. It is impossible to point out the exact 
age of each lobe, since some events comprised a period with several individual failures of varying size. The 1905 event caused erosion of the delta at Nesdal possibly implying that much landslide material was emplaced to the south. However, the 1936 rock-fall events caused erosion of the Bødalsdelta with dramatic impacts on the entire Lovatnet shoreline. It could imply that much of the emplaced material affected the main Lovatnet basin. Lobe $\mathrm{d}$ is potentially associated with failure in the Bødalsdelta and appears to be older, or of a similar age, to lobe 2 . Hence, lobe 3 that reaches far into the lake basin could either have originated from the 1936 event or may even be older. In addition, older landslide debris may be buried under the lobes, under the lake floor or in the toe of the Bødalsdelta (Figs. 7, 8, 9A). In the absence of absolute dating the age of each lobe is thus uncertain.

As previously described, the deposits are likely composed of a combination of rock fragments from the Ramnefjellet cliff with reworked talus, glacial debris, lake and delta sediments. This implies that debris from the undercut subaqueous slopes and remobilised lake sediments contributed to the total sediment mass added to the lake basin. The estimated volume of lobes 2 and 3 together is $>1.2 \times 10^{6} \mathrm{~m}^{3}$, which is a significant volume compared to the total of $3.0 \times 10^{6} \mathrm{~m}^{3}$ released from Ramnefjellet between 1905 and 1950, according to Grimstad \& Nesdal (1990). The debris from the Bødalsdelta in lobe $\mathrm{d}$ seems to have been partially entrained in and laterally limited by the main debris lobes from Ramnefjellet.

The narrow morphology of the lake basin near Ramnefjellet promoted a concentrated flow of debris along the lake floor, which helped acceleration of debris and water during the major events. The minor frontal deformations show that the mass flow was able to move relatively freely on the low-angle basin floor. A tsunami-wave movement was initiated and waves piled up at the outlet of the lake at Vassenden (Jørstad, 1968). The wave gave rise to a seiche movement of the entire lake volume. Wave action caused erosion along the shoreline as for example along the Raudi delta (Fig. 13). The returning waves swallowed several features at Vassenden and traces on the lake floor indicate that they were transported up to $c .1 .5 \mathrm{~km}$ into the northern lake basin (Fig. 11). Debris lobes were deposited at the base of the slopes and hydroplaning may have helped further transport of larger objects (e.g., Ilstad et al., 2004). This most likely included anthropogenic items that disappeared during the events (Fig. 11B).

There are other relatively young features identified on the lake floor that could potentially originate from Ramnefjellet but no chronology is available. Several cliffs along the shoreline were eroded and some shallow scars were formed during the events. Sediments were transported to the deeper parts of the basin and were deposited in lobes at the foot of marginal slopes or were buried. Larger, low-relief debris lobes on the northern basin floor below the Breng delta could result from failure along the shoreline and in the lake (Fig. 10). Relatively high backscatter values of the debris indicate a young age. Other features such as the sediment drape below Hellsetefjellet and minor failures and debris in deeper water could potentially be from the historical events or may even be older (Figs. 6, 10).

\section{The shaping of fan deltas and Bødalsdelta}

The deltas in Lovatnet display a high variability with regard to detailed morphology. Most deltas are colluvial and formed through a combination of fluvial and gravitational processes, except Bødalsdelta, which is fully alluvial. Some delta slopes have a smooth surface that most probably reflects a relatively steady and low sedimentation rate. By contrast, delta slopes with numerous channels and scars reflect failure and underflow activity most likely due to elevated sedimentation rates or active reworking processes. This behaviour could be the result of a relatively recent increase in sediment supply. This could be due to an occasional increase in fluvial activity and supply of sediment, for example due to landslide activity directly onto the deltas or in their catchments, such as at Raudi and at Breng. Another possible reason for a temporary increase could be glacier growth during the LIA.

The Bødalsdelta is the only one displaying large, transverse ridges as reported, e.g., from fjord deltas (e.g., Hill, 2012). The seismic data show lenses with varying internal reflection patterns indicative of failure and/or undercurrent activity (Fig. 15). The cliffs along several delta shorelines indicate that they were subjected to wave erosion such as from a tsunami event, and/or slope failure (e.g., Fig. 13). Undercutting by flow activity has also been important in some deltas. The Bødalsdelta could have been especially prone to erosion due to bottom flow activity caused by rock avalanches from Ramnefjellet, and some diffuse ridge features at the delta toe could represent partly buried debris (Fig. 8).

Several deltas in Lovatnet display local protuberances on the slope or irregular extensions at their toe, which are interpreted as indicative of special events in the deltas and/or their steep catchments. The identified features show that the regular deltaic sedimentation processes were interrupted and changed for a period. One of the most distinct examples is the promontory on the slope of the Bødalsdelta. The promontory is interpreted as the remains of a subaqueous fan that accumulated during enhanced flow activity and localised sedimentation followed by abandonment and incision. Its formation would require a fixed feeder channel and steady sediment source for a period, and might represent a delta construction phase caused by landslide activity. Other deltaic protuberances display various degrees of irregularity and are generally interpreted as landslide debris, maybe locally combined with sediments from increased underflow 
activity. This is exemplified at the toes of the Raudi and Helset deltas. Resumed delta sedimentation following the events resulted in partial burial of the debris. Major mass-wasting activity below Skavteigfjellet was followed by construction of a small delta body that only managed to cover a minor part of the debris. At Hellsete, onshore landslide debris confining the delta plain, major irregular debris at the delta toe, and a distinct debris lobe laterally to the delta slope, also indicate a significant influence of landslide and avalanche activity. Deltaic protuberances and other special features associated with delta collapse have been reported from other fjord-type lakes (e.g., Hilbe \& Anselmetti, 2014; Kremer et al., 2015). These authors have assigned such features to seismic events or overloading due to rock falls, respectively. In the Lovatnet case, these triggers are also relevant but other factors such as oversteepening and climate may also have played a role.

\section{Conclusions}

- High-resolution bathymetrical data from Lovatnet fjord-lake combined with onshore LiDAR data demonstrate the morphological variability of a glacially carved high-relief landscape in western Norway. Gravitational processes have affected most of the lake including the deltas and many parts of the basin floor even near the outlet.

- We present the morphological images of landslide debris at the base of Ramnefjellet that was subjected to major rock-failure events between 1905 and 1950 . Debris from the rock avalanches were transported at least $1.8 \mathrm{~km}$ into the lake including $1 \mathrm{~km}$ along the basin floor, leaving little frontal deformation. The debris is divided into three main lobes and a few, diffuse, lobe features at the base of the Bødalsdelta. Absolute ages are unknown and more debris is buried in the lake.

- A rough calculation of the total landslide volume of the two major lobes on the basin floor gives more than $1.2 \times 10^{6} \mathrm{~m}^{3}$. This is a significant quantity compared to the rock volume released from Ramnefjellet between 1905 and 1950. Undercutting of debris-covered slopes and remobilisation of lacustrine and alluvial sediments contributed to a high total volume of mobilised debris.

- The Ramnefjellet rock failures affected the entire lake, generated tsunamis and induced seiche-like movements. The returning wave motion from Vassenden seems to have generated bottom flows and debris lobes were deposited. Debris was transported from near shore and up to $1.5 \mathrm{~km}$ southwards along the lake floor. Hydroplaning was likely involved. The distinct features identified on the basin floor could potentially be the remains of anthropogenic objects, including a vessel that disappeared as a consequence of the tsunami waves. Bottom flows likely resulted in undercut slopes and failures elsewhere in the lake, and the wave motion caused erosion along the shoreline.

- Major deltaic protuberances reflect previously unknown events in the deltas or their catchments such as major landsliding. Examples are the extended delta toes of the Raudi and Hellsete deltas and a promontory on the Bødalsdelta slope.

- We identify other previously undocumented, major landslide debris originating from Hellsetefjellet and Skarvteigfjellet, in addition to debris protuberances in other deltas.

- A morphological high in the middle of the deepest lake basin has been identified. The feature appears to be deeply rooted and might represent bedrock, glacial debris or landslide material. Moreover, a mid-lake protuberance out of reach from most gravitational processes likely represents a buried glacier marginal feature.

- This study highlights the importance of morphological inventory mapping for further investigation and hazard assessment. Continuous work on seismic data and cores is needed to fully understand the paleoenvironmental and geohazard history of Lovatnet lake.

Acknowledgements. We thank Oddbjørn Totland and a local boat driver for technical assistance during fieldwork. Thanks to Astrid Lyså and Valentin Burki for help during the first data processing and to Fredrik Høgaas for preparing LiDAR data to be displayed in GIS. Flavio Anselmetti from the University of Bern is greatly thanked for his help during different stages of this study. Ilja de Winter and Adriaan Janszen assisted during the 2010 PES field campaign from Delft University of Technology. We are grateful for constructive reviews by Stein Bondevik and Maarten Van Daele. We also thank Oddvar Longva for comments, and Astor Furseth for useful historical information. Local people are thanked for their interest and helpfulness. David Roberts corrected the English language. Collection of high-resolution bathymetrical data was carried out within the SEDITRANS project founded by The Research Council of Norway (grant no. 160167). Seismic data (Airgun and Pinger) acquisition was funded by the Swiss National Science Foundation. The TUDelft PES campaign was funded by the IPY-NL program of the Organization for Scientific Research (NWO, grant no 851.40.080).

\section{References}

Bickerton, R.W. \& Matthews, J.A. 1993: "Little Ice Age" variations of outlet glaciers from the Jostedalsbreen ice cap, Southern Norway: a regional lichenometric-dating study of ice-marginal moraine sequences and their climatic significance. Journal of Quaternary Science 8, 45-66.

Bjerrum, L. \& Jørstad, F. 1968: Stability of rock slopes in Norway. Norwegian Geotechnical Institute Publication 79, 1-11.

Blikra, L.H. \& Nemec, W. 1998: Postglacial colluvium in western Norway: depositional processes, facies and palaeoclimatic record. Sedimentology 45, 909-959. 
Blikra, L.H., Longva, O., Braathen, A., Anda, E., Dehls, J. \& Stalsberg, K. 2006: Rock-slope failures in Norwegian fjord areas: Examples, spatial distribution and temporal patterns. In Evans, S.G., Scarawcia Mugnozza, G., Strom, A.L. \& Hermanns, R.L. (eds.): Massive Rock Slope Failure: New Models on Hazard Assessment, NATO Science Series, IV: Earth and Environmental, Sciences 49, Springer, Berlin, pp. 489-511.

Bozzano, F., Mazzanti, P., Anzidei, M., Esposito, C., Floris, M., Fasani, G.B. \& Esposito, A. 2009: Slope dynamics of Lake Albano (Rome, Italy): insights from high resolution bathymetry. Earth Surface Processes and Landforms 34, 1469-1486. doi: 10.1002/esp.1832.

Burki, V., Larsen, E., Fredin, O. \& Margreth, A. 2009: The formation of sawtooth moraine ridges in Bødalen, south-central Norway. Geomorphology 105, 182-192.

Burki, V., Hansen, L., Fredin, O., Andersen, T., Beylich, A., Jaboyedoff, M., Larsen, E. \& Tønnesen, J.F. 2010: Little Ice Age advance and retreat sediment budgets for an outlet glacier in western Norway. Boreas 39, 551-566.

Bøe, R., Rise, L., Blikra, L.H., Longva, O. \& Eide, A. 2003: Holocene mass-movement processes in Trondheimsfjorden, central Norway. Norwegian Journal of Geology 83, 3-22.

Bøe, R., Longva, O., Lepland, A., Blikra, L.H., Sønstegaard, E., Haflidason, H., Bryn, P. \& Lien, R. 2004: Postglacial mass movements and their causes in fjords and lakes in western Norway. Norwegian Journal of Geology 84, 35-55.

Chapron, E., Beck, C., Pourchet, M. \& Deconinck, J.F. 1999: 1822 earthquake-triggered homogenite in Lake Le Bourget (NW Alps). Terra Nova 11, 86-92.

Couchon-Voyer, G., Locat, J., Leroueil, S., St-Onge, G. \& Demers, D. 2011: Large-scale subaerial and submarine Holocene and recent mass movements in the Betsiamites area, Quebec, Canada. Engineering Geology 121, 28-45.

Fareth, O.W. 1987: Glacial geology of middle and inner Nordfjord, western Norway. Geolological Survey of Norway Bulletin 408, 1-55.

Furseth, A. 2006: Skredulykker i Norge. Tun Forlag, Grønland, Oslo, 207 pp. (In Norwegian).

Grimstad, E. 2005: The Loen rock slides - an analysis of the stability. In Senneset, K., Flaate, K. \& Larsen, J.O. (eds.): Landslides and Avalanches: ICFL 2005 Norway, Taylor \& Francis Group, London, pp. 129-135.

Grimstad, E. \& Nesdal, S. 1990: The Loen rockslides - A historical review. Norwegian Geotechnical Institute Publication 182, 1-6.

Haeussler, P.J., Parsons, T., Finlayson, D.P., Hart, P., Chaytor, J.D., Ryan, H., Lee, H., Labay, K., Peterson, A. \& Liberty, L. 2014: New Imaging of Submarine Landslides from the 1964 Earthquake Near Whittier, Alaska, and a Comparison to Failures in Other Alaskan Fjords. In Krastel, S., Behrmann, J.H., Völker, D., Stipp, M., Berndt, C., Urgeles, U., Chaytor, J., Huhn, K., Strasser, M. \& Hartbitz, C. (eds.): Submarine Mass Movements and Their Consequences, Advances in Natural and Technological Hazards Research 37, Springer International Publishing, Cham, pp. 361-370. doi: 10.1007/978-3-319-009728_32.

Hansen, L., Beylich, A.A., Burki, V., Eilertsen, R., Lyså, A., Nesje, A. \& Tønnesen, J.F. 2009: Stratigraphic architecture, infill history and controlling factors of a (de)glaciated bedrock-valley in Stryn, western Norway. Sedimentology 56, 1751-1773.

Hansen, L., L'Heureux, J.S., Longva, O., Eilertsen, R.S. \& Bøe, R. 2013: Mapping of subaqueous landforms for near-shore landslide susceptibility assessment in Norwegian fjords. In Margottini, C., Canuti, P. \& Sassa, K. (eds.): Landslide Science and Practice, Volume 5: Complex Environment, Springer, Berlin, pp. 89-94.

Helland, A. 1905: Raset på Ravnefjeld i Loen. Naturen 29, 161-172. (In Norwegian).

Hilbe, M. \& Anselmetti, F.S. 2014: Signatures of slope failures and riverdelta collapses in a perialpine lake (Lake Lucerne, Switzerland). Sedimentology 61, 1883-1907.

Hilbe, M., Anselmetti, F.S., Eilertsen, R.S., Hansen, L. \& Wildi, W. 2011:
Subaqueous morphology of Lake Lucerne (Central Switzerland): implications for mass movements and glacial history. Swiss Journal of Geosciences 104, 425-443.

Hill, P.R. 2012: Changes in submarine channel morphology and strata development from repeat multibeam surveys in the Fraser River delta, western Canada. In Li, M.Z., Sherwood, C.R. \& Hill, P.R. (eds.): Sediments, Morphology and Sedimentary Processes on Continental Shelves, International Association of Sedimentologists Special Publication 44, pp. 47-70.

Hjelstuen, B.O., Haflidason, H., Sejrup, H.P. \& Lyså, A. 2009: Sedimentary processes and depositional environments in glaciated fjord systems - Evidence from Nordfjord, Norway. Marine Geology 258, 88-99.

Holmsen, G. 1936: De siste bergskred i Tafjord og Loen, Norge. Meddelanden från Lunds Universitets Geografiske Institution 124, særtrykk ur Svensk Geografisk Årbok 1936. (In Norwegian with German summary).

Ilstad, T., De Blasio, F.V., Elverhøi, A., Harbitz, C.B., Engvik, L., Longva, O. \& Marr, J.G. 2004: On the frontal dynamics and morphology of submarine debris flows. Marine Geology 213, 481-497.

Jørstad, F. 1968: Waves generated by Landslides in Norwegian Fjords and Lakes. Norwegian Geotechnical Institute 73, 13-32.

Klakegg, O., Nordahl-Olsen, T., Sønstegaard, E. \& Aa, A.R. 1989: Sogn og Fjordane fylke Quaternary geology map, scale 1:250,000, Norges geologiske undersøkelse.

Kremer, K., Hilbe, M., Simpson, G., Decrouy, L., Wildi, W. \& Girardclos, S. 2015: Reconstructing 4000 years of mass movement and tsunami history in a deep peri-Alpine lake (Lake Geneva, FranceSwitzerland). Sedimentology 62, 1305-1327.

Larsen, E., Eide, F., Longva, O. \& Mangerud, J. 1984: Allerød- Younger Dryas climatic interferances from cirque glaciers and vegetational development in the Nordfjord area, Western Norway. Arctic Alpine Research 16, 137-160.

Ledoux, G., Lajeunesse, P., Chapron, E. \& St-Onge, G. 2010: Multibeam Bathymetry Investigations of Mass Movements in Lake Le Bourget (NW Alps, France) Using a Portable Platform. In Mosher, D.C., Moscardelli, Shipp, R.C., Chaytor, J.D., Baxter, C.D.P., Lee, H.J. \& Urgeles, R. (eds.): Submarine Mass Movements and Their Consequences, Advances in Natural and technological Hazards Research 28, Springer Science+Business Media B.V., Dordrecht, pp. 423-434.

L'Heureux, J.-S., Hansen, L. \& Longva, O. 2009: Development of the submarine channel at the mouth of the Nidelva River, Trondheimsfjorden, Norway, Marine Geology 260, 30-44.

L'Heureux, J.-S., Eilertsen, R.S., Glimsdal, S., Issler, D., Solberg, I.-L. \& Harbitz, C.B. 2012: The 1978 Quick Clay Landslide at Rissa, Mid Norway: Subaqueous Morphology and Tsunami Simulations. In Yamada, Y., Kawamura, K., Ikehara, K., Ogawa, Y., Urgeles, R., Mosher, D., Chaytor, J. \& Strasser, M. (eds.): Submarine Mass Movements and Their Consequences, Advances in Natural and Technological Hazards Research 31, Springer Science+Business Media B.V., Dordrecht, pp. 507-516. doi: 10.1007/978-94-007-2162$3 \_45$.

Lien, R. 1985: Kvartærgeologien i Bødalen, Loen, indre Nordfjord. Thesis, University of Bergen, $109+120$ pp.

Longva, O., Janbu, N., Blikra, L.H. \& Bøe, R. 2003: The 1996 Finneidfjord slide; seafloor failure and slide dynamics. In Locat, J. \& Mienert, J. (eds.): Submarine Mass Movements and Their Consequences, Kluwer Academic Publishers, Dordrecht, pp. 531538.

Lutro, O. 2003: Stryn, bedrock geology map 1318 I, scale 1:50,000. Foreløpig utgave plotteversjon. http://geo.ngu.no/kart/berggrunn/ (accessed December 2015).

Lyså, A., Hjelstuen, B.O. \& Larsen, E. 2010: Fjord infill in a high-relief area: Rapid deposition influenced by deglaciation dynamics, glacioisostatic rebound and gravitational activity. Boreas 39, 39-55.

Mangerud, J., Larsen, E., Longva, O. \& Sønstegaard, E. 1979: Glacial 
history of western Norway 15,000-10,000 B.P. Boreas 8, 179-187.

Mulder, T. \& Chapron, E. 2011: Flood deposits in continental and marine environments: Character and significance. In Slatt, R.M. \& Zavala, C. (eds.): Sediment transfer from shelf to deep waterRevisiting the delivery system, American Association of Petroleum Geologists Studies in Geology 61, pp. 1-30.

Nesdal, S. 2002: Lodalen -fager og färleg. Nordberg Aksidenstrykkeri, Oslo. 160 pp. (In Norwegian).

Nesje, A., Matthews, J.A., Dahl, S.O., Berrisford, M.S. \& Andersson, C. 2001: Holocene glacier fluctuations of Flatebreen and winterprecipitation changes in the Jostedalsbreen region, western Norway, based on glacio-lacustrine sediment records. Holocene 11, 267-280.

Postma, G. 1990: Depositional architecture and facies of river and fan deltas: a synthesis. In Colella, A. \& Prior, D. (eds.): Coarse-Grained Deltas, International Association of Sedimentologists Special Publication 10, pp. 13-27.

Prior, D.B. \& Bornhold, B.D. 1990: The underwater development of Holocene fan deltas. In Colella, A. \& Prior, D. (eds.): Coarse-Grained Deltas, International Association of Sedimentologists Special Publication 10, pp. 75-90.

Reusch, H. 1907: Skredet i Loen 15de januar 1905. Norges geologiske undersøkelse aarbok 45, Aschehoug \& co, Kristiania, 20 pp. (In Norwegian with English summary).

Romstad, B., Harbitz, C.B. \& Domaas, U. 2009: A GIS method for assessment of rock slide tsunami hazard in all Norwegian lakes and reservoirs. Natural Hazards and Earth System Science 9, 353-364.

Rye, N., Nesje, A., Lien, R., \& Anda, A. 1987: The Late Weichselian ice sheet in the Nordfjord-Sunnmøre area and deglaciation chronology for Nordfjord, western Norway. Norsk Geologisk Tidsskrift 41,23-43.

Rye, N., Nesje, A., Lien, R., Blikra, L.H., Eikenæs, O. \& Hole, P.A. 1997: Glacial geology and deglaciation chronology of the area between inner Nordfjord and Jostedalsbreen-Strynefjellet, western Norway. Norsk Geologisk Tidsskrift 77, 51-63.

Schnellmann, M., Anselmetti, F.S., Giardini, D. \& McKenzie, J.A. 2006: 15,000 Years of mass-movement history in Lake Lucerne: Implications for seismic and tsunami hazards. Eclogae Geologicae Helvetiae 99, 409-428. doi: 10.1007/s00015-006-1196-7.

Svendsen, J.I. \& Mangerud, J. 1987: Late Weichselian and Holocene sea-level history for a cross-section of western Norway. Journal of Quaternary Science 2, 113-132.

Van Daele, M., Versteeg, W., Pino, M., Urrutia, R. \& De Batist, M. 2013: Widespread deformation of basin-plain sediments in Aysén fjord (Chile) due to impact by earthquake-triggered, onshore-generated mass movements. Marine Geology 337, 67-79. doi: http://dx.doi. org/10.1016/j.margeo.2013.01.006.

Van Daele, M., Moernaut, J., Doom, L., Boes, E., Fontijn, K., Heirman, K., Vandoorne, W., Hebbeln, D., Pino, M., Urrutia, R., Brümmer, R. \& De Batist, M. 2015: A comparison of the sedimentary records of the 1960 and 2010 great Chilean earthquakes in 17 lakes: Implications for quantitative lacustrine palaeoseismology. Sedimentology 62, 1466-1496. doi: 10.1111/sed.12193.

Vasskog, K., Nesje, A., Støren, E.N., Waldmann, N., Chapron, E. \& Aritzegui, D. 2011: A Holocene record of snow-avalanche and flood activity reconstructed from a lacustrine sedimentary sequence in Oldevatnet, western Norway. The Holocene 21, 597-614.

Vasskog, K., Waldmann, N., Bondevik, S., Nesje, A., Chapron, E. \& Aritzegui, D. 2013: Evidence for Storegga tsunami run-up at the head of Nordfjord, western Norway. Journal of Quaternary Science $28,391-402$.

Wiemer, G., Moernaut, J., Stark, N., Kempf, P., De Batist, M., Pino, M., Urrutia, R., de Guevara, B.L., Strasser, M. \& Kopf, A. 2015: The role of sediment composition and behavior under dynamic loading conditions on slope failure initiation: a study of a subaqueous landslide in earthquake-prone South-Central Chile. International Journal of Earth Sciences 104, 1439-1457. doi: 10.1007/s00531-0151144-8. 